\title{
A Proposed Enzyme-Linked Hydrogen Peroxide Radical Assay System (HORAS)
}

\author{
by \\ EunJee Park \\ B.Sc., Ryerson University, 2014 \\ A thesis presented to Ryerson University \\ in partial fulfillment of the requirements for the degree of Master of Science \\ in the program of Molecular Science
}

Toronto, Ontario, Canada, 2017

(C) EunJee Park “2017” 


\section{AUTHOR'S DECLARATION FOR ELECTRONIC SUBMISSION OF A THESIS}

I hereby declare that I am the sole author of this thesis. This is a true copy of the thesis, including any required final revisions, as accepted by my examiners.

I authorize Ryerson University to lend this thesis to other institutions or individuals for the purpose of scholarly research.

I further authorize Ryerson University to reproduce this thesis by photocopying or by other means, in total or in part, at the request of other institutions or individuals for the purpose of scholarly research.

I understand that my thesis may be made electronically available to the public 


\title{
A Proposed Enzyme-Linked Hydrogen Peroxide Radical Assay System (HORAS)
}

\author{
EunJee Park
}

Master of Science, Molecular Science, Ryerson University, 2017

\begin{abstract}
Reactive Oxygen Species (ROS) are chemically reactive molecules that contain oxygen. ROS are naturally generated as a byproduct during mitochondrial oxidative metabolism as well as by cellular responses to a variety of inflammatory stimuli. Intracellularly formed ROS plays an important role in maintaining homeostasis and in cell signaling but, ROS are challenging to quantify. Phagocytic cells such as macrophages may produce $\mathrm{H}_{2} \mathrm{O}_{2}$ during the action of bacterial engulfment. Here UV-Vis versus LC-ESI-MS detection methods for an enzyme-linked, cellular assay of $\mathrm{H}_{2} \mathrm{O}_{2}$ production in cultured macrophages are compared. In the presence of Horseradish Peroxidase (HRP), Amplex Red (AR) reacts with $\mathrm{H}_{2} \mathrm{O}_{2}$ in a 1:1 stoichiometry to produce the redfluorescent oxidation product resorufin that can be measured by UV/Vis at an absorbance of 570 $\mathrm{nm}$ or by LC-ESI-MS at $214 \mathrm{~m} / \mathrm{z}[\mathrm{M}+\mathrm{H}]^{+}$. RAW 264.7 macrophages were stimulated by microscopic foreign particles, with the addition of $0.1 \mathrm{mM}$ of Amplex Red substrate and $10 \mathrm{ng} / \mathrm{mL}$ of HRP to the cellular media to enzymatically detect $\mathrm{H}_{2} \mathrm{O}_{2}$ production. The oxidation product resorufin can be detected by the colorimetric method as low as 50 pmol while liquid chromatography with electrospray ionization and mass spectrometry (LC-ESI-MS) was able to detect as little as $0.2 \mathrm{pmol}$ in vitro. Thus, it was possible to measure low levels of $\mathrm{H}_{2} \mathrm{O}_{2}$ released by cells using an enzyme coupled cellular assay with LC-ESI-MS.
\end{abstract}




\section{ACKNOWLEDGEMENTS}

I wish to thank Dr. John Marshall who gave me the opportunity to research this thesis. Thank you for being so understanding. He supported me for years and was always there to help me, and to encourage me to never give up. I am so glad for a doing this amazing project with him.

I also would like to thank and acknowledge the significant contributions made by Angelique Florentinus, whose expertise was essential to the completion of this important work. As well, my lab mates Jaimie Dufresne and Thanusi Thavarajah for continued support and friendship.

Lastly, I want to thank my parents, my sister, and my friends. I would not have been able to finish this project without their support and love. Thank you for being around me during the time when I needed you. Without your love and support, I would have not been able to achieve what I have now. 


\section{TABLE OF CONTENTS}

AUTHOR'S DECLARATION FOR ELECTRONIC SUBMISSION OF A THESIS ............ ii

ABSTRACT ................................................................................................................................................ iii

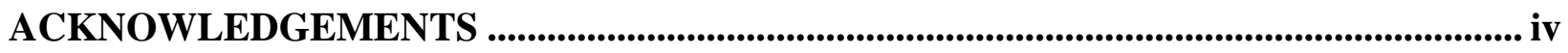

LIST OF FIGURES ............................................................................................................. vi

LIST OF APPENDICES ........................................................................................................ viii

LIST OF SELECTED ABBREVIATIONS............................................................................ ix

CHAPTER 1:Introduction ................................................................................................................... 1

$1.1 \quad$ Reactive Oxygen Species .......................................................................................... 1

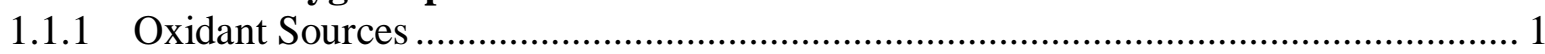

1.1.2 Antioxidant Defense Systems ............................................................................ 3

$1.2 \quad \mathrm{H}_{2} \mathrm{O}_{2}$ Production in Macrophages ....................................................................................... 5

1.3 Hydrogen Peroxide Detection Method ................................................................................... 7

CHAPTER 2:MATERIALS and METHODS _................................................................ 13

$2.1 \quad$ Materials ............................................................................................................................. 13

2.2 Method ............................................................................................................................................. 13

CHAPTER 3:RESULTS ....................................................................................................... 18

3.1 Determination of Optimal conditions for Amplex Red Assay .................................... 18

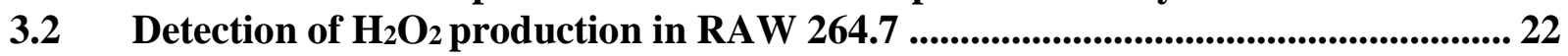

3.3 Determination of Optimal Conditions for ECL Experimentation ............................ 31

3.4 Detection of $\mathrm{H}_{2} \mathrm{O}_{2}$ production in RAW 264.7 using LC-ESI-MS.............................. 36

CHAPTER 4:DISCUSSION ............................................................................................................ 44

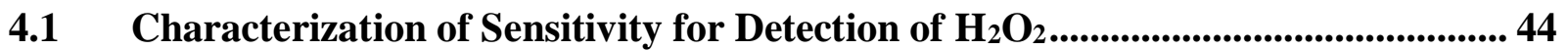

4.2 Measurement of $\mathrm{H}_{2} \mathrm{O}_{2}$ Production ................................................................................4 45

4.3 Luminol Dependent Chemiluminescent ............................................................................. 46

4.4 Mass spectrometry .............................................................................................................. 46

CHAPTER 5:CONCLUSION ............................................................................................. 48

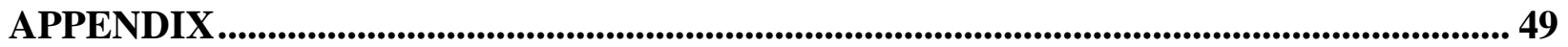

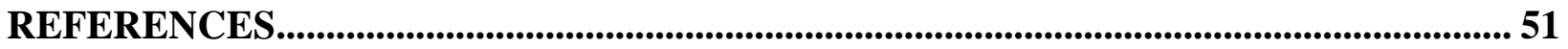




\section{LIST OF FIGURES}

Figure 1.1 Non-fluorescent Amplex red is oxidized by the horseradish peroxidase and hydrogen peroxide to highly fluorescent Resorufin. 7

Figure 1.2 Cell permeable DCFH-DA is cleaved by intracellular esterase to DCFH and oxidized by hydrogen peroxide to the fluorescent molecule. 8

Figure $1.3 \mathrm{O}_{2}{ }^{--}$reduces lucigenin $\left(\mathrm{LC}^{2+}\right)$ to its cation radical $\left(\mathrm{LC}^{++}\right)$. Cation radical reacts with a second $\mathrm{O}_{2}{ }^{--}$to form the energy-rich dioxetane molecule $\left(\mathrm{LCO}_{2}\right)$ and results in emitting of a photon.

Figure 1.4 Luminol oxidized by hydrogen peroxide with presence of HRP to the fluorescent molecule. 10

Figure 1.5 A typical ESR spectrometer is formed by a resonator cavity surrounded by a pair of electrical magnets and a microwave generator that emits radiation towards the cavity............... 11

Figure 3.1 Time course of the change in fluorescence of oxidation product of AR.................... 19 Figure 3.2 To optimize the reaction conditions by producing HRP standard curves in vitro reaction.. 20

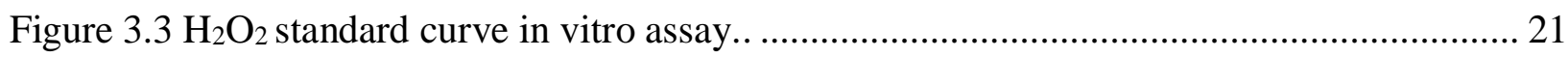

Figure 3.4 A colorimetric cellular HRP assay measured by UV/Vis spectrometry...................... 23

Figure 3.5 A colorimetric cellular HRP assay measured by UV/Vis spectrometry....................... 24

Figure 3.6 A colorimetric cellular HRP assay measured by UV/Vis spectrometry...................... 25

Figure 3.7 Production of resorufin from the activation of the macrophage respiratory burst measured by enzyme-catalyzed oxidation of AR assay............................................................ 26

Figure 3.8 A cellular HRP assay measured effect of beads coated oxLDL on antioxidant enzymes

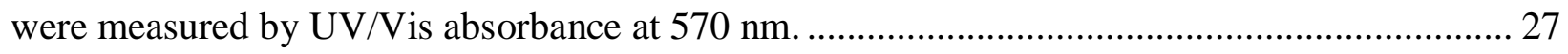
Figure 3.9 To test enzyme-catalyzed oxidation of AR using beads by measuring absorbance at 570 nm.. .28

Figure 3.10 A hydrogen peroxide and reactive oxygen species cellular assay was measured by

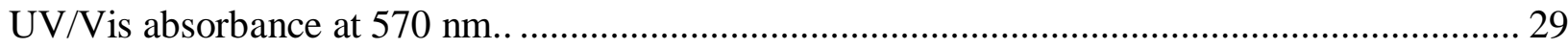

Figure 3.11 The production of $\mathrm{H}_{2} \mathrm{O}_{2}$ by RAW 264.7 macrophages in response to microbeads... 30

Figure 3.12 The detection of HRP and $\mathrm{H}_{2} \mathrm{O}_{2}$ using the ECL method........................................ 32 Figure 3.13 The image analysis of the HRP standard curves quantified using Image Lab software (see Figure 3.13.A).. 
Figure 3.14 The oxidation of luminol in the presence of increasing $\mathrm{H}_{2} \mathrm{O}_{2}$ was measured by BioTek microplate reader..

Figure 3.15 The ECL reaction measured on methanol activated PVDF with increasing HRP and $\mathrm{H}_{2} \mathrm{O}_{2}$. 35

Figure 3.16 Standard curve of resorufin by liquid chromatography with electrospray ionization and mass spectrometry (LC-ESI-MS).. 37

Figure 3.17 The Resorufin standard curve as measured by LC-ESI-MS.. 38 Figure 3.18 Resorufin recovery test using EtOH extraction. Cultured RAW 264.7 cells in 6 well for 48 hours and added isotonic experiment media ( $\mathrm{pH} 7.4)$

Figure 3.19 Resorufin recovery test: direct injection of resorufin versus zip-tiping $200 \mu l$ of resorufin sample and detected by liquid chromatography with electrospray ionization and mass spectrometry (LC-ESI-MS). 40 Figure 3.20 The production of $\mathrm{H}_{2} \mathrm{O}_{2}$ by Raw 264.7 cells in response to oxLDL coated beads and stimulator was measured by LC-ESI-MS. 41 Figure 3.21 The production of $\mathrm{H}_{2} \mathrm{O}_{2}$ by Raw 264.7 cells in response to oxLDL coated beads and stimulator was measured by LC-ESI-MS was computed to bar graph using Figure 3.20.......... 42 Figure 3.22 The production of $\mathrm{H}_{2} \mathrm{O}_{2}$ by Raw 264.7 cells in response to ligand coated beads and stimulator was measured by LC-ESI-MS calculated to find moles of resorufin using the resorufin standard curve (see Figure 3.18). 43 


\section{LIST OF APPENDICES}

Figure A. $195 \%$ family-wise confidence level for simultaneous measurement of $\mathrm{H}_{2} \mathrm{O}_{2}$ production using the combination of enzyme-linked $\mathrm{H}_{2} \mathrm{O}_{2}$ radical assay............................................ 49 Figure A. $295 \%$ family-wise confidence level for simultaneous measurement of $\mathrm{H}_{2} \mathrm{O}_{2}$ production using the combination of enzyme-linked $\mathrm{H}_{2} \mathrm{O}_{2}$ radical assay and LC-ESI-MS... 50 


\section{LIST OF SELECTED ABBREVIATIONS}

ADS Antioxidant defense systems

AR Amplex red

ECL Enhanced chemiluminescence

ESI Electro spray ionization

ESR Electron spin resonance

FAD Flavin adenine dinucleotide

GPx Glutathione peroxidase

GSH $\gamma$-glutamylcyseinylglycine

HRP Horseradish peroxidase

$\mathrm{H}_{2} \mathrm{O}_{2}$ Hydrogen peroxide

IgG Immunoglobulin G

LOQ Safe Limit detection and quantification

MS Mass spectrometry

NADPH Nicotinamide adenine dinucleotide phosphate

NOX NADPH oxidases

oxLDL Oxidized low density lipoprotein

PBS phosphate buffered saline

PMA Phorbol 12-myristate 13-acetate

ROS Reactive oxygen species

SOD Superoxide dismutase

Tris Tris (hydroxymethyl) aminomethane 
SD Standard Deviation

SE Standard Error 


\section{CHAPTER 1: Introduction}

\subsection{Reactive Oxygen Species}

Atomic oxygen is inclined to accept electrons and form reactive oxygen species due to the unpaired electrons in the outer electron shell. There are six different kinds of reactive oxygen species (ROS): Oxygen, superoxide, peroxide, hydrogen peroxide, hydroxyl radical, and hydroxyl ion. Molecular oxygen is crucial for the survival of aerobic organisms. Aerobic energy metabolism is dependent on complete reduction of a molecule of oxygen to water which requires four electrons and several sequential intermediates. These intermediates are considered as ROS, and ROS are highly reactive compared to molecular $\mathrm{O}_{2}$. The most common ROS in cells are Superoxide, Hydrogen peroxide, and Hydroxyl radical.

\subsubsection{Oxidant Sources}

\section{Mitochondria}

ROS include several reactive molecules and free radicals derived from one or more unpaired electron oxygen molecules. All aerobic cells produce ROS, such as superoxide anion, hydrogen peroxide, and hydroxyl radical in various enzymes and organelles within the cell. Cells produce ROS as a byproduct of many metabolic reactions in the mitochondria, peroxisomes, the endoplasmic reticulum (ER) and particularly in the setting of ER stress (Halliwell \& Gutteridge, 1984). Mitochondria may be a major site of ROS production in response to physiological reactions under aerobic conditions (Chance et al., 1979). During mitochondrial oxidative phosphorylation, Complex I (NADH-ubiquinone oxidoreductase) and Complex III (Q-cytochrome c oxidoreductase) transfer a single electron to the oxygen molecule. Thus, superoxide anion $\left(\mathrm{O}_{2}{ }^{-}\right)$is initially formed by the electron transfer chain in inner mitochondrial membrane (Turrens et al., 1985). Superoxide anion can be converted to $\mathrm{H}_{2} \mathrm{O}_{2}$ by an enzyme called super oxide dismutase (SOD) which is located 
in the intermembrane space of mitochondria (McCord \& Fridovich, 1969 and Weisiger \& Fridovich, 1973). About $0.1 \%$ to $0.5 \%$ of mitochondrial $\mathrm{O}_{2}$ consumption leads to $\mathrm{H}_{2} \mathrm{O}_{2}$ production enzymatically or spontaneously (Bayne et al., 2005 and Boveris et al., 1972).

\section{NADPH oxidases}

Reactive oxygen species were initially considered as unwanted by-products of other biological reactions since they were known to cause cell membrane and DNA damage. However, Sbarra and Karnovsky (1995) first observed a sudden increase in oxygen consumption during phagocytosis which was dependent on glucose metabolism. The NADPH oxidase complex is the primary enzyme system which is responsible for respiratory bursts (Rossi \& Zatti, 1964). Superoxide anion $\left(\mathrm{O}_{2}{ }^{-}\right)$production occurs during phagocytosis via the NOX2 complex, also known as gp91 ${ }^{\text {phox }}$, as part of their essential role in host defense (Babior et al., 1973 and Teahan et al, 1987).

All NADPH oxidases (NOX) enzymes are composed of six highly conserved transmembrane domains which contain two hemes, NADPH and FAD binding regions at the $\mathrm{COOH}$ terminus (Bedard \& Krause, 2007). In phagocytes, NOX2 and p22 phox are found in both intracellularly and in plasma membranes with four cytosolic proteins (p47 phox $, p 67^{\text {phox }}, \mathrm{p} 40^{\text {phox }}$, and Rac). During phagocytosis, NOX2 assembles by recruiting cytosolic proteins, exchanging GDP to GTP on Rac, to become an active enzyme complex (Holmström \& Finkel, 2014). Phosphorylation of the cytosolic $\mathrm{p} 47^{\text {phox }}$ allows interaction with $\mathrm{p} 22^{\text {phox }}$ and leads to the recruitment of other cytoplasmic subunits, $\mathrm{p} 67^{\text {phox }}$ and $\mathrm{p} 40^{\text {phox }}$, to form the active NOX2 enzyme complex. The active form of NOX2 transports electron from cytosolic NADPH to extracellular or phagosomal oxygen to generate superoxide anions which is also known as the respiratory burst (Bedard \& Krause, 2007). 


\section{Other Enzymes}

Mitochondria and NOX enzymes are well characterized intracellular sources of ROS. Studies have shown various enzymes such as xanthine oxidase, nitric oxide synthase, cyclooxygenases, cytochrome p450 enzymes, and lipoxygenases can also produce trace amount of ROS (Holmström \& Finkel, 2014). Similarly, peroxisomes and endoplasmic reticulum (ER) may also produce ROS depending on cell type.

\subsubsection{Antioxidant Defense Systems}

Different intracellular concentrations of ROS may have various biological effects. ROS may serve as signaling molecules. For example, concentrations of $10^{-8} \mathrm{M}$ of $\mathrm{H}_{2} \mathrm{O}_{2}$ is involved in growth signaling while concentrations of $10^{-4} \mathrm{M}$ of $\mathrm{H}_{2} \mathrm{O}_{2}$ leads to apoptosis (Stone and Yang, 2006). ROS homeostasis is essential since imbalanced ROS may damage macromolecules including; DNA, protein, and lipids. This damage may cause cell damage or death. In order to counterbalance the production of ROS, cells have Antioxidant Defense Systems (ADS) to scavenge excessively produced ROS. ADS can be divided by enzymatic antioxidants and non-enzymatic antioxidants.

\section{Enzymatic Antioxidants}

Enzymatic antioxidants work by breaking down and removing free radicals. The major antioxidant enzymes are superoxide dismutase (SOD), catalase, and glutathione peroxidase that maintain the cellular reductive potential and each antioxidant has distinct functions. Two superoxide molecules are converted to $\mathrm{H}_{2} \mathrm{O}_{2}$ and $\mathrm{O}_{2}$ by SOD. Three different isoforms of SOD; CuZn-SOD, Mn-SOD, and EC-SOD have been identified (Zelko et al., 2002). CuZn-SOD is a copper and zinc-containing homodimer found in intracellular cytoplasmic spaces of mammalian cells. The tetramer form of 
Mn-SOD is exclusively found in the mitochondrial spaces of aerobic cells while EC-SOD was first identified in the extracellular spaces of human plasma (Zelko et al., 2002).

Catalase is a well-recognized antioxidant enzyme that is found in nearly all aerobic organisms. Catalase is mainly localized in peroxisomes but is also found in the cytosol of human neutrophils and alveolar macrophages to catalyze the composition of $\mathrm{H}_{2} \mathrm{O}_{2}$ to water and oxygen (Davies et al, 1979).

Another enzyme that responsible for the reduction of $\mathrm{H}_{2} \mathrm{O}_{2}$ is glutathione peroxidase (GPx). GPx are a family of tetrameric enzymes that dependent on the micronutrient selenium (Se) at the active site and uses low-molecular-weight thiols, such as $\gamma$-glutamylcyseinylglycine (GSH), to reduce $\mathrm{H}_{2} \mathrm{O}_{2}$ via the following reactions (Imai \& Nakagawa, 2003):

Glutathione Peroxidase (GPx): $2 \mathrm{GSH}+\mathrm{H}_{2} \mathrm{O}_{2} \rightarrow \mathrm{GSSG}+2 \mathrm{H}_{2} \mathrm{O}$

\section{Non-Enzymatic Antioxidants}

Non-enzymatic antioxidants work by interrupting free radical chain reactions. A few examples of the non-enzymatic antioxidants are vitamin $\mathrm{C}$, vitamin $\mathrm{E}$, and GSH. The water-soluble antioxidants including vitamin C (ascorbic acid) are present in cellular fluids such as the cytosol, or cytoplasmic matrix by scavenging oxygen free radicals (Birben et al., 2012). The lipid-soluble antioxidant vitamin E is found in cell membranes and protects against oxidant induced membrane injury. Vitamin C and vitamin E can be activated by GSH which is localized in all compartments. GSH is the major soluble antioxidant, and can function as an antioxidant in numerous ways (Nimse \& Pal, 2015). GSH reduces hydrogen peroxide to water and oxygen. In addition, GSH is a cofactor for detoxifying enzymes such as GPx. The oxidized form of glutathione (GSSG) is reduced, and so recycled, by glutathione reductase (GRD) enzymes, with NADPH as a reductant: 
GRD: GSSG+NADPH+H $\mathrm{H}^{+} \rightarrow 2 \mathrm{GSH}+\mathrm{NADP}^{+}$

\section{$1.2 \mathrm{H}_{2} \mathrm{O}_{2}$ Production in Macrophages}

\section{Macrophages}

Macrophages are mononuclear cells capable of phagocytosis which play a significant role in immunity and immune responses (Epelman et al., 2015). They are distributed throughout mammalian organs and their morphology varies depending on their state of activity.

\section{Phagocytosis}

Cells have a variety of ways to internalize particle and solutes such as pinocytosis, receptor mediated endocytosis and phagocytosis. Phagocytosis, first observed in 1884 by Ilyich Metchnikoff, is the uptake large particles $(>0.5 \mu \mathrm{m})$ into cells by actin-dependent mechanisms (Aderem \& Underhill, 1999). Phagocytosis occurs by sequential interactions between macrophages surface receptors and opsonic ligand on surfaces of particles.

\section{Oxidized Low-Density Lipoprotein produces Reactive Oxygen Species in Macrophages}

Oxidized Low-Density Lipoprotein (oxLDL) is generated from native LDL that plays a role as a cholesterol transporter and accumulates in atherosclerotic lesions in humans (Yia-Herttuala et al., 1989). The accumulation of oxLDL in atherosclerotic lesion causes atherosclerosis (Liu et al., 2006). Macrophages scavenger receptors such as CD36 bind and engulf accumulated oxLDL and become foam cells that induce inflammatory reactions within the arterial walls which, also contributes to atherosclerosis (Yang et al., 2007 and Itabe, 2009 and Han \& Nicholson, 1998). A previous study showed that an 8 hour treatment with $20 \mu \mathrm{g} / \mathrm{ml}$ of oxLDL increased ROS generation in RAW264.7 cells causing an increase in NOX2 mRNA expression and protein levels (Lee et al., 2014). Thus, production of intracellular ROS by a signaling cascade through NOX family NADPH 
oxidases may act as a second messenger in the inflammatory response. Studies have shown that oxLDL stimulates phagocytosis in macrophages causing activation of inflammation signaling molecules (Bae et al., 2009 and Lee et al., 2014).

\section{Physiological Role of Hydrogen Peroxide}

All aerobic cells have various enzymes to eliminate $\mathrm{H}_{2} \mathrm{O}_{2}$ since it is toxic to cells and damages macromolecules. Despite its toxicity, cells produce $\mathrm{H}_{2} \mathrm{O}_{2}$ for a variety of functions in cells. Only phagocytic cells use $\mathrm{H}_{2} \mathrm{O}_{2}$ as a defense mechanism since phagocytic cells may depend on $\mathrm{H}_{2} \mathrm{O}_{2}$ to help degrade engulfed particles (Baehner et al., 1975). Recent studies have shown that $\mathrm{H}_{2} \mathrm{O}_{2}$ is also produced in response to activation at the cell surface, which may function as an intracellular messenger in cells. Unlike other messenger molecules, $\mathrm{H}_{2} \mathrm{O}_{2}$ is a ubiquitous intracellular messenger that oxidizes critical residues of effector protein to activate various function in cells

(Woo et al., 2010). In general, $\mathrm{H}_{2} \mathrm{O}_{2}$ responds to different signaling pathways depending on the cell type, the magnitude of the dose, and the duration of the cell exposures. When $\mathrm{H}_{2} \mathrm{O}_{2}$ concentration is $10^{-8}$ to $10^{-7} \mathrm{M}$, cells proliferate (Giorgio et al., 2007). $10^{-7}$ to $10^{-5} \mathrm{M}$ of $\mathrm{H}_{2} \mathrm{O}_{2}$ can cause either temporary or permanent growth arrest, while oxidative stress $\left(10^{-4} \mathrm{M}\right.$ of $\left.\mathrm{H}_{2} \mathrm{O}_{2}\right)$ causes cell death by apoptotic or necrotic mechanisms. Oxidative stress is highly studied since it may cause diseases such as atherosclerosis, diabetes, pulmonary fibrosis, neurodegenerative disorders, arthritis, and aging (Finkel \& Holbrook, 2000). Thus, it is important to quantify and track the small diffusible $\mathrm{H}_{2} \mathrm{O}_{2}$ molecules in live cells. 


\subsection{Hydrogen Peroxide Detection Method}

To clearly understand cell signaling events, it is important to accurately detect and quantify ROS like $\mathrm{H}_{2} \mathrm{O}_{2}$. Several techniques and analytical approaches such as fluorescence and chemiluminescence have been used to detect $\mathrm{H}_{2} \mathrm{O}_{2}$.

\section{Fluorescent probes}

There are many methods that have been examined to measure $\mathrm{H}_{2} \mathrm{O}_{2}$ in real-time. An effective way to measure $\mathrm{H}_{2} \mathrm{O}_{2}$ is using Amplex Red (AR) in the presence of Horseradish Peroxidase (HRP). Non-fluorescent molecules of AR are converted to highly fluorescent resorufin by reacting with $\mathrm{H}_{2} \mathrm{O}_{2}$ at a stoichiometry of 1:1 when HRP catalyzes an $\mathrm{H}_{2} \mathrm{O}_{2}$ dependent oxidation (Figure 1.1). This assay is sensitive to 2 pmol of $\mathrm{H}_{2} \mathrm{O}_{2}$ (Mohanty et al., 1997). HRP has a high catalysis rate and yield but, it is also one of the least specific enzymes of the peroxidase family thus HRP could utilize many cellular compounds including thiols for its substrate.

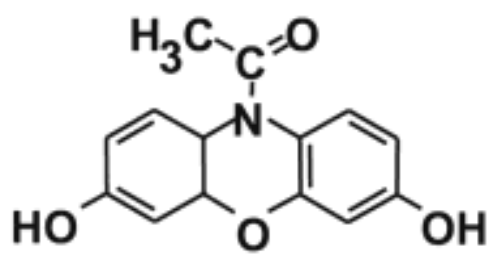

N-Acetyl-3,7-Dihydroxyphenoxazine (Amplex Red)

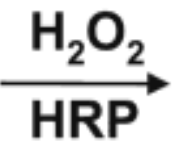

Resorufin Highly fluorescent

Figure 1.1 Non-fluorescent Amplex red is oxidized by the horseradish peroxidase and hydrogen peroxide to highly fluorescent Resorufin (Dikalov, Griendling, \& Harrison, 2007)

Dichlorodihydrofluorescein diacetate (DCFH-DA) is also commonly used to detect intracellular $\mathrm{H}_{2} \mathrm{O}_{2}$ and oxidative stress. DCFH-DA is a cell permeable non-fluorescent probe that can be hydrolyzed by intracellular esterases (Kalyanaraman et al., 2010). Two electron oxidation 
of DCFH forms the fluorescent product dichlorofluorescein (DCF) (Figure 1.2). DCF can be monitored by several fluorescence-based techniques such as confocal microscopy and flow cytometry which allows for the measurement of $\mathrm{H}_{2} \mathrm{O}_{2}$ concentration over time. However, the intracellular redox chemistry of DCFH is complex and the DCF assay has several limitations to measure intracellular $\mathrm{H}_{2} \mathrm{O}_{2}$. As Figure 1.2 shows, DCFH does not directly react with $\mathrm{H}_{2} \mathrm{O}_{2}$ to form DCF, and therefore cannot be used as direct measurement of $\mathrm{H}_{2} \mathrm{O}_{2}$. In addition, redox active metals such as $\mathrm{Fe}^{2+}$ with presence of $\mathrm{H}_{2} \mathrm{O}_{2}$ can oxidize DCFH to form DCF results in amplification of fluorescent signal intensity (Karlsson et al., 2010).

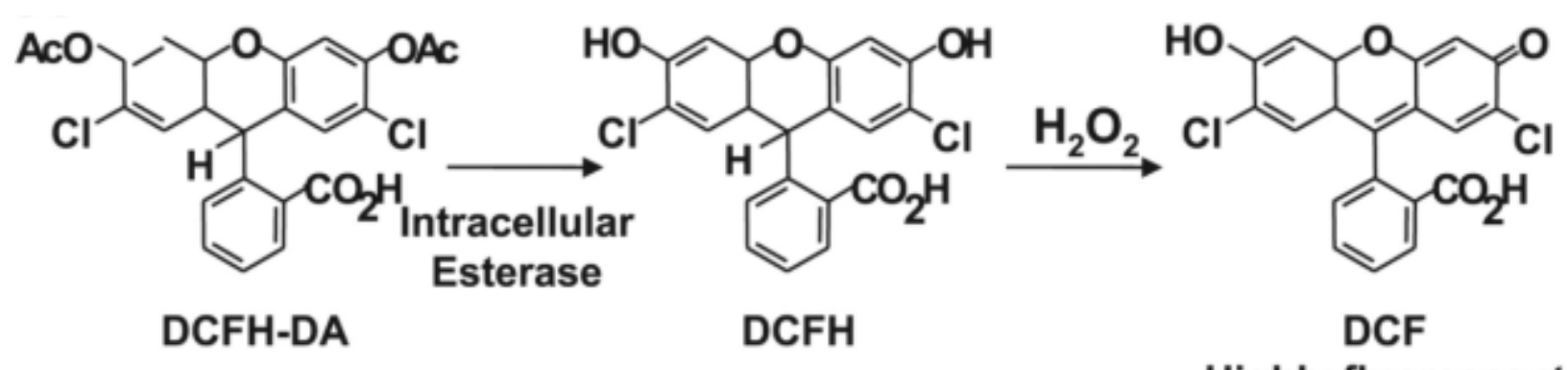

Highly fluorescent

Figure 1.2 Cell permeable DCFH-DA is cleaved by intracellular esterase to DCFH and oxidized by hydrogen peroxide to the fluorescent molecule (Dikalov et al., 2007).

\section{Chemiluminescent probes}

Commonly used chemiluminescence probes are lucigenin, luminol, MCLA [2-Methyl-6(4-methoxyphenyl)-3,7-dihydroimidazo[1,2-a] pyrazin-3-one, hydrochloride] and coelentarzine. To measure superoxide, lucigenin-enhanced chemiluminescene (LEC) may be used since it is reasonably specific for $\mathrm{O}_{2}^{--}$and its signal is linear. LEC are also easily detected by a scintillation counter or a luminometer (Dikalov et al., 2007 and Rost et al., 1998). Lucigenin-amplified chemiluminescence reactions are as follows (Faulkner \& Fridovich, 1993): 
Reaction. 1: $\mathrm{O}_{2}{ }^{\cdot-}+\mathrm{LC}^{2+} \rightarrow \mathrm{LC}^{\cdot+}+\mathrm{O}_{2}$

Reaction. 2: $\mathrm{LC}^{\cdot+}+\mathrm{O}_{2} \cdot-\rightarrow \mathrm{LCO}_{2}$

Reaction. 3: $\mathrm{LCO}_{2} \rightarrow 2 N$-methylacridone $+\mathrm{h} v$

The lucigenin radical can react with $\mathrm{O}_{2}{ }^{--}$to form NMA and a photon (Figure 1.3). However, $\mathrm{O}_{2}{ }^{--}$ production can be overestimated by redox cycling (Rost et al., 1998). In addition, chemiluminescence based assays are easy and specific for superoxide but other ROS can only be measured by use of inhibitors.<smiles></smiles>

Lucigenin $\left(\right.$ Luc $\left.^{2+}\right)$<smiles></smiles>

Lucigenin cationradical $\left(\cdot\right.$ Luc $\left.^{+}\right)$

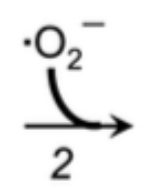<smiles>CN(C)c1ccccc1C(=O)N1c2ccccc2C(O)c2ccccc2N1C</smiles>

Lucigenin dioxetane (Luc $=\mathbf{O}_{2}$ )<smiles>CN1C(=O)C2C=CC=CC2=[N+](C)c2ccccc21</smiles>

N-Methylacridinium (NMA)

$\mathrm{NMA}^{*} \rightarrow \mathrm{NMA}+$ photon

Figure $1.3 \mathrm{O}_{2}^{\cdot-}$ reduces lucigenin $\left(\mathrm{LC}^{2+}\right)$ to its cation radical $\left(\mathrm{LC}^{\cdot+}\right)$. Cation radical reacts with a second $\mathrm{O}_{2}{ }^{--}$to form the energy-rich dioxetane molecule $\left(\mathrm{LCO}_{2}\right)$ and results in emitting of a photon (Vladimirov \& Proskurnina, 2009).

The enhanced chemiluminescence luminol dependent (ECL) assay is another attractive analytical method to measure $\mathrm{H}_{2} \mathrm{O}_{2}$ since it is highly sensitive with a fast reaction time. The chemiluminescence of luminol can be catalyzed by different catalyst compounds such as copper (II) and hexacyanoferrate (III) in hydrogen peroxide assays (Steijger et al., 1996 and Yoshida et al., 1999). Several studies have found that ECL has a great potential to measure $\mathrm{H}_{2} \mathrm{O}_{2}$ by providing 
more intense, prolonged, and stable light emission proportional to $\mathrm{H}_{2} \mathrm{O}_{2}$ concentration. In basic media in the presence of catalyzers and oxidants with the addition of an electron rich compound (enhancer), luminol emits light at 425nm (Bhandari et al., 2010; Ramos et al., 2001; Navas et al., 1996) (Figure 1.4).

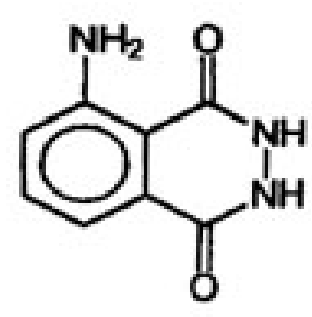

Luminol

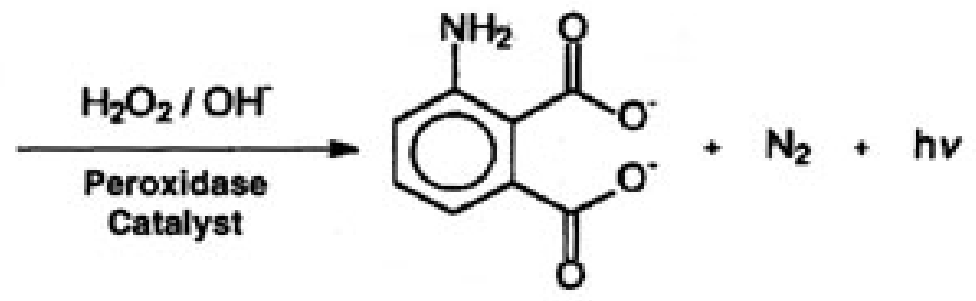

Amino phthalat

Figure 1.4 Luminol oxidized by hydrogen peroxide with presence of HRP to the fluorescent molecule. The amount of light detected is proportional to the hydrogen peroxide concentration.

\section{Electron Spin Resonance (ESR)}

Electron spin resonance (ESR) or also known as electron paramagnetic resonance (EPR) spectroscopy is formed by a microwave generator, a resonator, and electrical magnets (Figure 1.5). ESR is an analytical technique based on absorption of microwave radiation stimulated by an electromagnetic field in molecules such as free radicals and transition metal ions with unpaired electrons (Dikalove et al., 2007). 


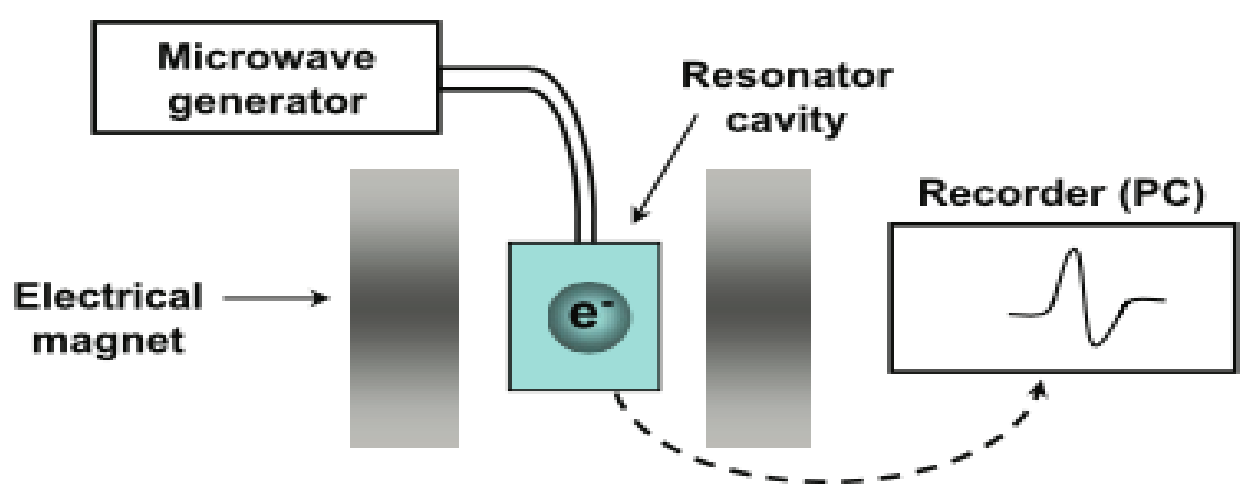

Figure 1.5 A typical ESR spectrometer is formed by a resonator cavity surrounded by a pair of electrical magnets and a microwave generator that emits radiation towards the cavity (Dikalove et al., 2007).

The unpaired electrons are excited to a high-energy state under the magnetic field by the absorption of microwave radiation ((Dikalove et al., 2007 and Konhno, 2010 and Lee et al., 2012). The excited electron changes its direction of spin and relaxes to ground state by emitting energy. The transition between two different energy levels takes place by absorbing a quantum of radiation of frequency in the microwave region. Microwave absorption is measured as a function of the magnetic field by ESR spectrometer. Although ESR is extremely sensitive and specific it is extremely expensive and requires certain probes such as cyclic hydroxylamines (Lee, et al., 2012). In addition, an ESR spectrometer requires an extra antioxidant or inhibitor experiment to verify presence of $\mathrm{H}_{2} \mathrm{O}_{2}$ since some other reaction may yield the radical products or oxidant which result in amplification of the ESR signal.

\section{New Methods for $\mathrm{H}_{2} \mathrm{O}_{2}$ Detection}

Previous studies have shown that oxidation of AR by HRP produced fluorescent resourfin that can be detected by liquid chromatography with electrospray ionization and tandem mass spectrometry 
(LC-ESI-MS) (Florentinus-mefailoski, Safi, \& Marshall, 2013). Resorufin was analyzed by HPLC-MS and SIM at 214m/z results in the log linear dilution curve as low as at $200 \mathrm{fmol}$ on column. The combination of enzyme-linked $\mathrm{H}_{2} \mathrm{O}_{2}$ radical assay and LC-ESI-MS can yield sensitivity to the fmol range with reduction of quantification and detection limit.

\section{Rationale and Objective}

Reactive oxygen species detection in macrophages has always been challenging due to the lack of techniques that are sensitive for low-level detection at the cellular level. The objective of this work was to apply liquid chromatography, electrospray ionization and mass spectrometry in order to monitor $\mathrm{H}_{2} \mathrm{O}_{2}$ concentrations in cultured macrophages in response to inflammatory signals. Oxidized AR products can be detected by liquid chromatography with electrospray ionization and mass spectrometry (LC-ESI/MS) at $214 \mathrm{~m} / \mathrm{z}[\mathrm{M}+\mathrm{H}]$. Thus, the mass spectral detection method to an enzyme coupled cellular assay may provide greater sensitivity and simplicity to measure $\mathrm{H}_{2} \mathrm{O}_{2}$ in live cells. 


\section{CHAPTER 2: MATERIALS and METHODS}

\subsection{Materials}

Horseradish peroxidase (HRP), $\mathrm{H}_{2} \mathrm{O}_{2}$, Ampliflu red (10-acetyl-3,7 dihydroxyphenoxazine), resorufin, luminol, 4-Iodophenylboronic acid (4-IPBA), Sodium orthovanadate, PMA, Ionomycin, superoxide dismutase, catalase were purchased from SigmaAldrich. Tris-HCl were purchased from BioShop. MaxiSorp 96well plates were obtained from Nunc (ThermoFisher Scientific). Cell culture flasks and 6well culture plates were obtained from Greiner Bio One. PVDF membrane was obtained from Millipore (Billerica, MA, USA). The solvents of optical grade were obtained from Caledon Laboratories (Georgetown ON, Canada). The LTQ ion trap was obtained from Thermo Fisher Scientific (Thermo Electron Corporation, Waltham MA, USA). The HPLC was from Agilent Technologies (Santa Clara CA, USA).

\subsection{Method}

\section{Substrate reactions}

HRP $(1 \mathrm{mg} / \mathrm{ml})$ was made to $50 \%$ glycerol and stored at $-20{ }^{\circ} \mathrm{C}$. Amplex red (AR) $5 \mathrm{mg}$ was dissolved in dry dimethyl sulfoxide (DMSO) and aliquots were stored in the dark at $-20{ }^{\circ} \mathrm{C}$. Amplex red was mixed in the reaction buffer (Tris $20 \mathrm{mM}, \mathrm{pH}$ 8.8) with a final substrate concentration of $0.1 \mathrm{mM}$. A total of $10 \mathrm{ng} / \mathrm{ml}$ of the HRP was added to reactions for time course measurements. The substrate and enzyme were mixed just prior to the addition of the $\mathrm{H}_{2} \mathrm{O}_{2}$ solution. For enhanced chemiluminescence (ECL), luminol was dissolved in dry DMSO and stored at $-20{ }^{\circ} \mathrm{C}$ until dissolved in Tris buffer $(\mathrm{pH} 8.8)$ and reacted in the presence of 4-iodophenylboronic acid and $10 \mathrm{ng} / \mathrm{ml}$ of the HRP with addition of different concentration of $\mathrm{H}_{2} \mathrm{O}_{2}$ mixed just prior to the detection. 


\section{Cell Culture}

RAW 264.7 cells were grown to $50 \%$ confluence in $75 \mathrm{~cm}$ flasks with Dulbecco's modified Eagle's medium (DMEM) supplemented with 5\% fetal bovine serum (FBS). Cells were plated at 25\% confluence in 6-well plates for 72 hours prior to assay; $1 \mathrm{~mL}$ of $\sim 50 \%$ confluent cell culture per well. Prior to the experiment to reduce the presence of extraneous growth medium proteins, the cells were washed with PBS for three times. Isotonic experimental medium (20 nM HEPES, $5 \mathrm{mM}$ glucose, $140 \mathrm{nM} \mathrm{NaCl}$, and $1 \mathrm{mM}$ of each $\mathrm{CaCl}_{2}$ and $\mathrm{MgCl}_{2}$ ) were added.

\section{Lipoprotein Isolation and Oxidation}

A total of $0.4451 \mathrm{~g} \mathrm{KBr}$ and $0.9 \mathrm{~mL}$ of normal human plasma were mixed into a Beckman $3 \mathrm{~mL}$ ultracentrifuge tube (McFarlane et al., 2005). A $0.196 \mathrm{M}$ solution of $\mathrm{NaCl}$ was gently run down the side onto the top of the plasma without disturbing the layers that occurred. Ultracentrifugation was performed at $4^{\circ} \mathrm{C}$, at $100,000 \mathrm{rpm}$ for 1 hour with an acceleration and deceleration setting of six. After ultracentrifugation, LDL was transferred to a $2 \mathrm{ml}$ O-ring tube using $21 \mathrm{G}$ needle and, placed into the $0.5 \mathrm{mM}$ EDTA containing PBS dialyzed at $4{ }^{\circ} \mathrm{C}$ for overnight (Shen et al., 2008). Oxidation was performed using isolated LDL placed in PBS containing $5 \mu \mathrm{M} \mathrm{CuSO}_{4}$ at $37^{\circ} \mathrm{C}$ for 18 hours. To terminate the reaction $0.3 \mathrm{mM}$ EDTA and $40 \mu \mathrm{M}$ butylated hydroxytoluene was incubated and dialyzed at $4{ }^{\circ} \mathrm{C}$ for overnight. Modified LDL was dialyzed extensively at $4^{\circ} \mathrm{C}$ against PBS containing $0.5 \mathrm{mM}$ EDTA. Prepared oxLDL $(\sim 0.0125 \mathrm{mg} / \mu \mathrm{l})$ was stored in the dark at $4{ }^{\circ} \mathrm{C}$.

\section{Preparation of IgG coated beads}

$15 \mu \mathrm{L}$ of $10 \mathrm{mg} / \mathrm{mL}$ human IgG dissolved in PBS was combined with $1.5 \mu \mathrm{L}$ of $2 \mu \mathrm{m}$ particles made of melamine resin (Fluka, Sigma-Aldrich, Product of Germany), diluted in $500 \mathrm{uL}$ of $1 \mathrm{x}$ phosphate buffered saline (PBS), and incubated for 30 min prior to washing three times after 
pelleting IgG coated beads at 148,000 rpm, and after removing the supernatant containing unbound IgG. IgG coated beads were re-suspended in 50uL of PBS.

\section{Preparation of oxLDL coated beads}

The same procedure was used to produce oxLDL coated beads as the IgG coated beads however the oxLDL coated beads were incubated in the dark due to light sensitivity.

\section{Enzyme reactions in 6 wells}

AR $(0.1 \mathrm{mM})$ and $10 \mathrm{ng} / \mathrm{ml}$ of HRP were added into 6 well plates where cells were grown. There were different treatments: beads, beads coated with IgG, beads coated with oxLDL, oxLDL coated beads with 500 units/ml SOD and 1000 units/ml catalase, $1 \mu \mathrm{M}$ PMA, $1 \mu \mathrm{M}$ ionomycin, $1 \mathrm{mM}$ sodium orthovanadate, and $\mathrm{H}_{2} \mathrm{O}_{2}$. Sodium orthovanadate, SOD (500 unit/ml) and Catalase (1000 unit $/ \mathrm{ml}$ ) were added 30 minutes prior to addition of $0.1 \mathrm{mM} \mathrm{AR}$ and $10 \mathrm{ng} / \mathrm{ml}$ of $\mathrm{HRP}$. Each treatment was incubated for 30 minutes and stored at $37^{\circ} \mathrm{C}$ and $5 \% \mathrm{CO}_{2}$ in the dark. After 30 mintues, reactions were quenched by placing onto ice.

\section{Colorimetric Detection}

The oxidation of non-fluorescent $\mathrm{AR}$ by $\mathrm{HRP}$ in the presence of $\mathrm{H}_{2} \mathrm{O}_{2}$ was monitored by UV/Vis spectroscopy. AR reacts with $\mathrm{H}_{2} \mathrm{O}_{2}$ in $1: 1$ stoichiometric ratio to produce resorufin that can be

detected colorimetrically. The plate was read on the microplate fluorimeter (Multiskan spectrum, Model number 354, Thermo labsystems) at $570 \mathrm{~nm}$ after 30 minutes of incubation by transferring $200 \mathrm{uL}$ of supernatants into 96 wells.

\section{Enhanced chemiluminescent (ECL) detection}

In the case of ECL, the limit of sensitivity for $\mathrm{H}_{2} \mathrm{O}_{2}$ was measured by adding $10 \mathrm{ng} / \mathrm{ml}$ of $\mathrm{HRP}$ and ECL solution (1.25 mM of luminol and $2.5 \mathrm{mM}$ of enhancer) into 96 well plate with different 
concentrations of $\mathrm{H}_{2} \mathrm{O}_{2}$ and detected by Bio-Rad gel doc system as well as microplate reader (Synergy HTX, BioTek Instruments, Inc, Winooski, USA). The amount of generated light is proportional to $\mathrm{H}_{2} \mathrm{O}_{2}$ concentration. To test limit of sensitivity using ECL, dot blotting $10 \mathrm{ng} / \mu \mathrm{l}$ of HRP onto methanol-activated PVDF in the presence of $1.25 \mathrm{mM}$ luminol and the enhancing agent $2.5 \mathrm{mM}$ of 4-iodophenylboronic acid and with detection by BIO-RAD gel doc (Haan \& Behrmann, 2007).

\section{Liquid Chromatography-Electrospray Ionization Mass spectrometry}

A $1 \mathrm{ml}$ volume of $0.1 \mathrm{mM}$ AR reacted with $\mathrm{H}_{2} \mathrm{O}_{2}$ at a stoichiometry of $1: 1$ with $10 \mathrm{ng} / \mathrm{ml}$ of HRP to yield oxidation product, resorufin. To concentrate and desalt the resorufin from the media, 200 $\mu \mathrm{L}$ of supernatant was collected by zip-tipping. To equilibrate the $\mathrm{C} 18$ ziptip (EMD Millipore) was pipette up the $65 \%$ acetonitrile (ACN) with 5\% FA buffer for ten times and washed in 5\% formic acid (FA) for ten times. To collect resorufin, the $200 \mu \mathrm{L}$ supernatant was pushed through the resin bed 20 times before washing in 5\% FA. Resorufin was eluted in 65\% ACN with 5\% FA in $2 \mu \mathrm{L}$. The resorufin was diluted 10 -fold in $5 \%$ formic acid. The LC-ESI-MS analysis was performed by manual injection of $20 \mu \mathrm{L}$ of the sample via an Agilent 1100 high pressure liquid chromatography (HPLC) pump set at 70\% acetonitrile and 30\% water to a final of $0.1 \%$ acetic acid as the ionization buffer flowing at $10 \mu \mathrm{L}$ per minute at $5 \mathrm{kV}$ over $15 \mathrm{~cm} \times 300 \mathrm{um}$ of normal phase column.

\section{Statistics}

Data shown are the means of blank \pm 3Standard deviation (SD) for limit of detection or means \pm SE of at least three independent experiments performed in triplicate as indicated in the figure legends. Comparison between control and treatment was made using $t$ test $(\mathrm{P} \leq 0.05)$ or comparison 
between groups by one-way ANOVA $(\mathrm{P} \leq 0.05)$ followed by a Tukey test or two-way ANOVA $(\mathrm{P} \leq 0.05)$ was used to compare difference of each treatment of $\mathrm{H}_{2} \mathrm{O}_{2}$ production by the statistical analysis system R. A value of $P<0.05$ was considered statistically significant. 


\section{CHAPTER 3: RESULTS}

\subsection{Determination of Optimal conditions for Amplex Red Assay}

Before using a colorimetric method, the reaction conditions were optimized and demonstrated linearity with respect to time, $\mathrm{HRP}$, and $\mathrm{H}_{2} \mathrm{O}_{2}$ standard curves in vitro (Figure 3.1, Figure 3.2, Figure 3.3). The lowest detection limit for HRP was $10 \mathrm{pg}$ and safe detection limit was above 50 pg (Figure 3.2). Similarly, using the optimized reaction, $\mathrm{H}_{2} \mathrm{O}_{2}$ concentration was measured from $0.25 \mu \mathrm{M}$ to $1 \mathrm{mM}$ and a linear relationship was found between $0.25 \mu \mathrm{M}$ to $100 \mu \mathrm{M}$ of $\mathrm{H}_{2} \mathrm{O}_{2}$ concentration and absorbance at $570 \mathrm{~nm}$, with a correlation coefficient of 0.99 . Using the AR and HRP reaction, $0.05 \mathrm{nmol}$ of $\mathrm{H}_{2} \mathrm{O}_{2}$ can be measured (Figure 3.3). The limit of safe detection for quantification (LOQ) was computed using blank of Mean+3SD=0.061. The lowest safe detection limit was $0.5 \mathrm{nmol} \mathrm{H}_{2} \mathrm{O}_{2}$. 


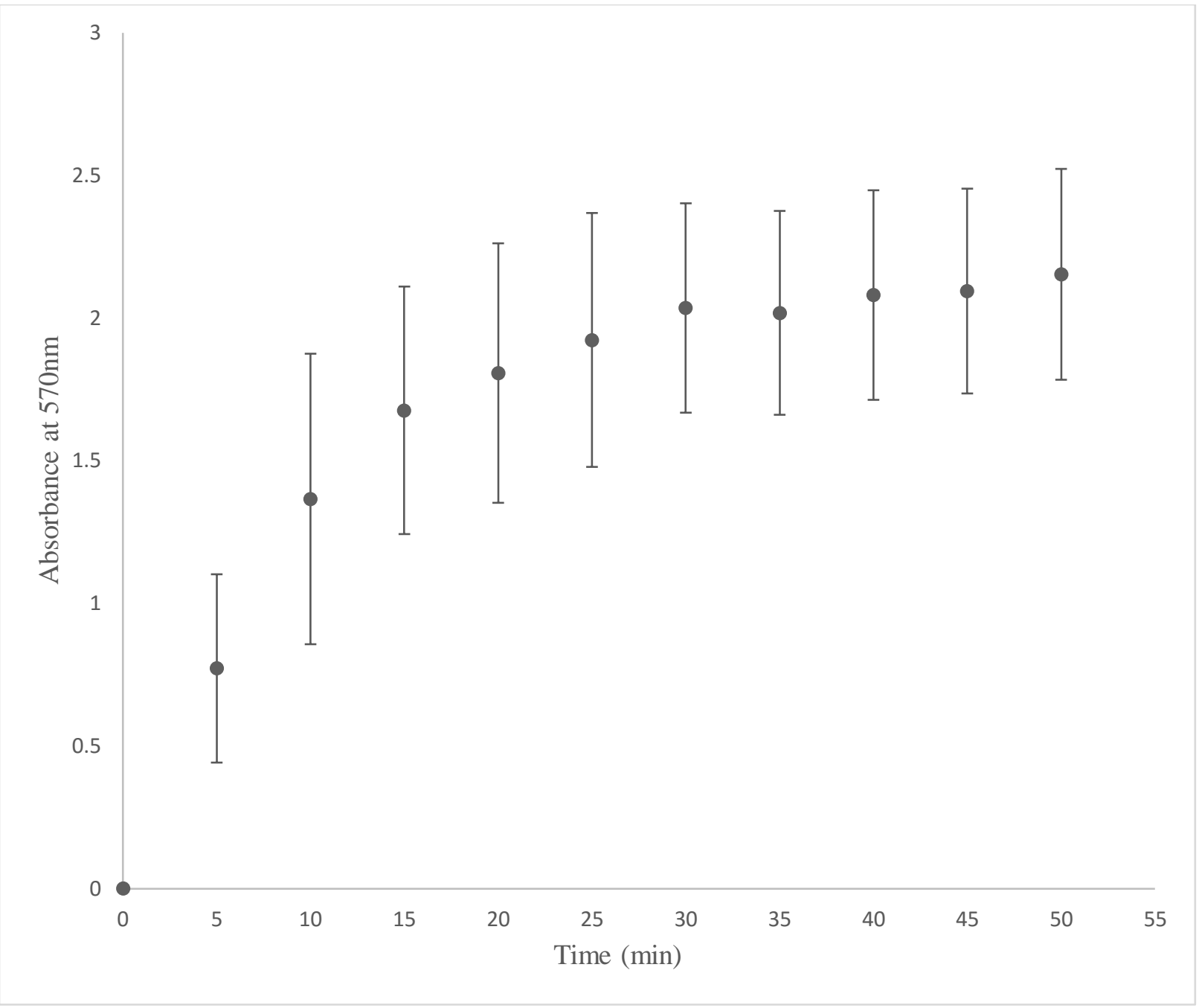

Figure 3.1 Time course of the change in fluorescence of oxidation product of AR. A $2 \mathrm{mM}$ of $\mathrm{H}_{2} \mathrm{O}_{2}$ was added into $0.1 \mathrm{mM}$ of AR and $10 \mathrm{ng} / \mathrm{ml}$ of $\mathrm{HRP}$ in total volume of $200 \mathrm{~mL}$ mixture to determine the optimal reaction time. Reactions were completed after $\sim 30 \mathrm{~min}$. Absorbance was measured using a microplate fluorimeter at $570 \mathrm{~nm}$. Data points were the mean of triplicate measurements with the standard error bars. 


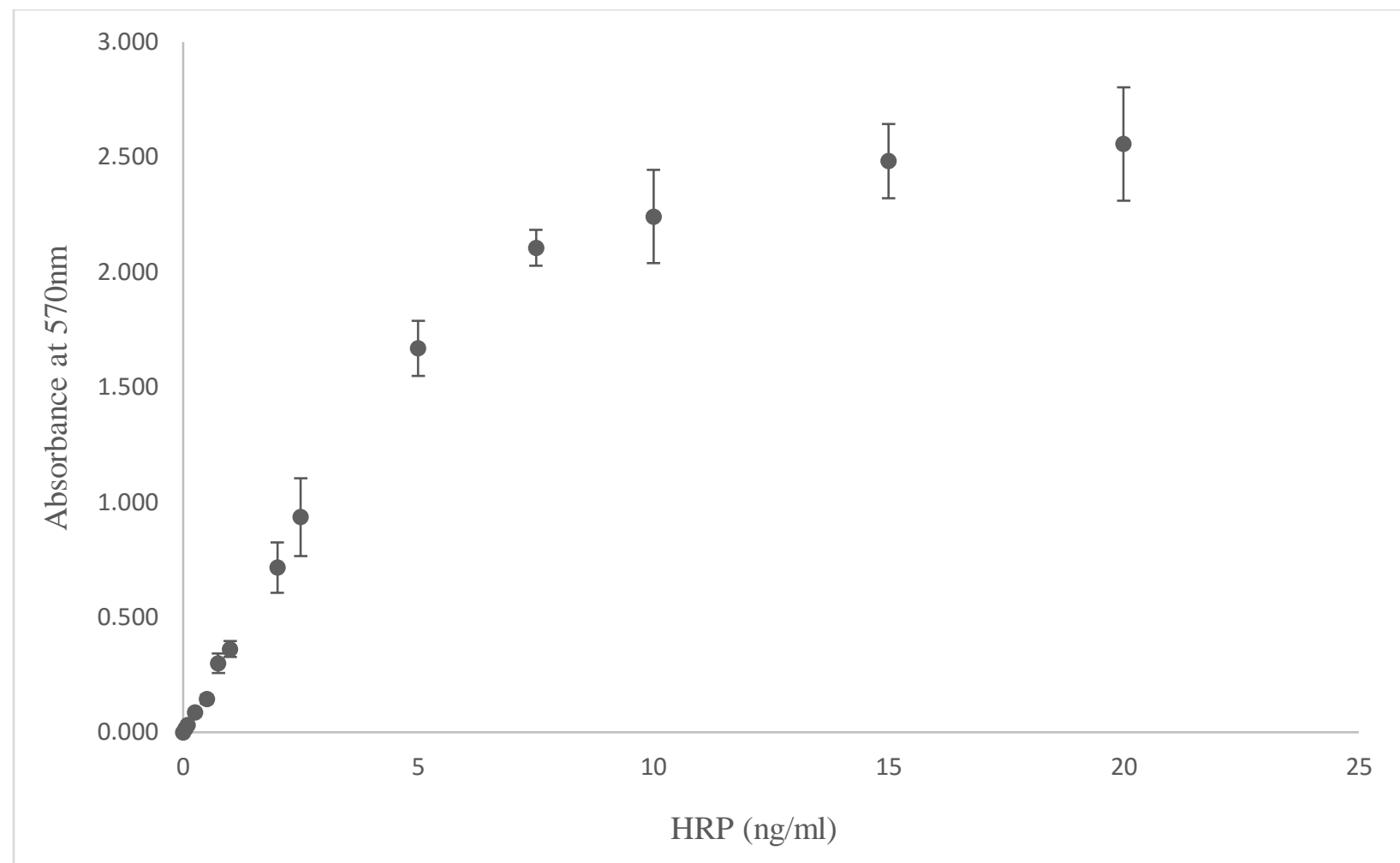

Figure 3.2 To optimize the reaction conditions by producing HRP standard curves in vitro reaction. The HRP concentration response to $0.05 \mathrm{ng} / \mathrm{ml}$ in total volume of $200 \mu \mathrm{L}$ in the presence of $0.1 \mathrm{mM}$ AR and $2 \mathrm{mM} \mathrm{H} \mathrm{O}_{2}$ into 96 wells. The plate was read on the microplate fluorimeter at $570 \mathrm{~nm}$ after $15 \mathrm{~min}$ of incubation in dark. To $0.05 \mathrm{ng} / \mathrm{ml}$ of HRP can be detected, but the LOQ was $0.25 \mathrm{ng} / \mathrm{ml}$ (Mean of blank+3SD=0.051, N=3). After $5 \mathrm{ng} / \mathrm{ml}$, reaction curve reached a plateau. The relationship between HRP and absorbance at $570 \mathrm{~nm}$ from $0.05 \mathrm{ng} / \mathrm{ml}$ to $5 \mathrm{ng} / \mathrm{ml}$. Data points are the mean of triplicate measurements and some of the standard error (S.E.) are not visible due to small deviations. 


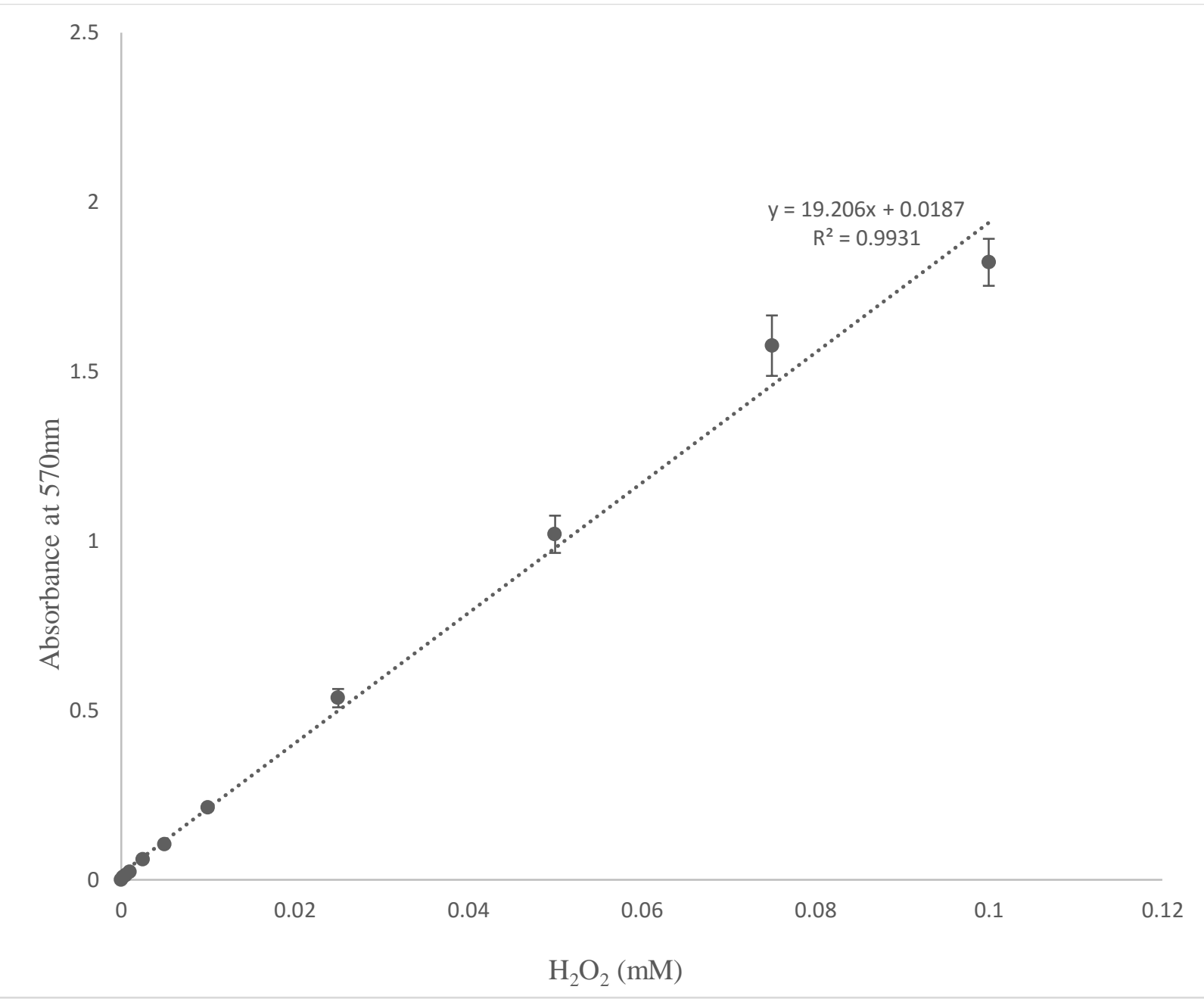

Figure $3.3 \mathrm{H}_{2} \mathrm{O}_{2}$ standard curve in vitro assay. The effect of different concentrations of $\mathrm{H}_{2} \mathrm{O}_{2}$ on UV/V is absorbance at $570 \mathrm{~nm}$, with AR as the HRP substrate. The HRP concentration was $10 \mathrm{ng} / \mathrm{ml}$ with $0.1 \mathrm{mM}$ of AR in total volume of $200 \mu \mathrm{L}$ into 96 wells. The plate was read on the microplate fluorimeter at $570 \mathrm{~nm}$ after $30 \mathrm{~min}$ of incubation. After addition of above $0.1 \mathrm{mM} \mathrm{H}_{2} \mathrm{O}_{2}$, reaction curve reached a plateau. The lowest detection level of $\mathrm{H}_{2} \mathrm{O}_{2}$ was 0.05 nmol while LOQ was $0.5 \mathrm{nmol}$ per $200 \mu \mathrm{l}$ (Mean of blank+3SD=0.061). Data points are the mean of triplicate measurements and S.E. are not visible due to small deviations. 


\subsection{Detection of $\mathrm{H}_{2} \mathrm{O}_{2}$ production in $\mathrm{RAW} 264.7$}

After determining the optimal concentration of AR, HRP, and $\mathrm{H}_{2} \mathrm{O}_{2}$ for experimentation, it was applied the optimized conditions to measure $\mathrm{H}_{2} \mathrm{O}_{2}$ in RAW264.7 cells. A phagocytic cell can be stimulated by microscopic foreign particles such as aggregated oxLDL and Immunoglobulin G (IgG) opsonized bacteria or by soluble stimulants such as PMA or chemotactic peptides such as N-formly-met-leu-phe. Different treatments were used to elicit an oxidative response including: melamine beads, beads coated in IgG, beads coated in oxLDL, ionomycin, PMA, cytochalasin B \& N-fromyl- met-leu-phe, and sodidum orthovanadate to investigate whether the cells could be stimulated to release measurable amounts of resorufin by fluorescence at $570 \mathrm{~nm}$.

When RAW 264.7 cells stimulated with PMA for 5min incubation, it showed significant increase of $\mathrm{H}_{2} \mathrm{O}_{2}$ production. Since catalase and SOD are the main mechanisms for conversion of super oxide to $\mathrm{H}_{2} \mathrm{O}_{2}$ and then $\mathrm{H}_{2} \mathrm{O}$, SOD and catalase were added in 30 min prior to addition of the treatment (oxLDL coated beads). When macrophages were treated with oxLDL coated beads and PMA, they produced the highest absorbance of resorufin compared to oxLDL alone, beads alone, and sodium orthovanadate (Figure 3.10). The confidence intervals using the Tukey method for oxLDL coated beads and oxLDL coated beads with SOD and catalase comparisons yield showed biologically significant difference (Figure A. 1). Figure 3.10 demonstrated that results are biologically significant using R. One Way-ANOVA test resulted in $\mathrm{F}(5,83)=10.91, p=4.35 \mathrm{e}^{-0.85}$. Multy-way ANOVA test resulted in $\mathrm{F}(5,83)=10.911, \mathrm{p}=4.351 \mathrm{e}^{-08}$. However, blank of mean $+3 \mathrm{SD}$ was 0.0574 and all treatment was not above LOQ except treatment with PMA. Using the line of the best fit $(y=19.206 x+0.0187)$ generated from the $\mathrm{H}_{2} \mathrm{O}_{2}$ standard curve, the yield of $\mathrm{H}_{2} \mathrm{O}_{2}$ in each treatment was computed (Figure 3.11). 


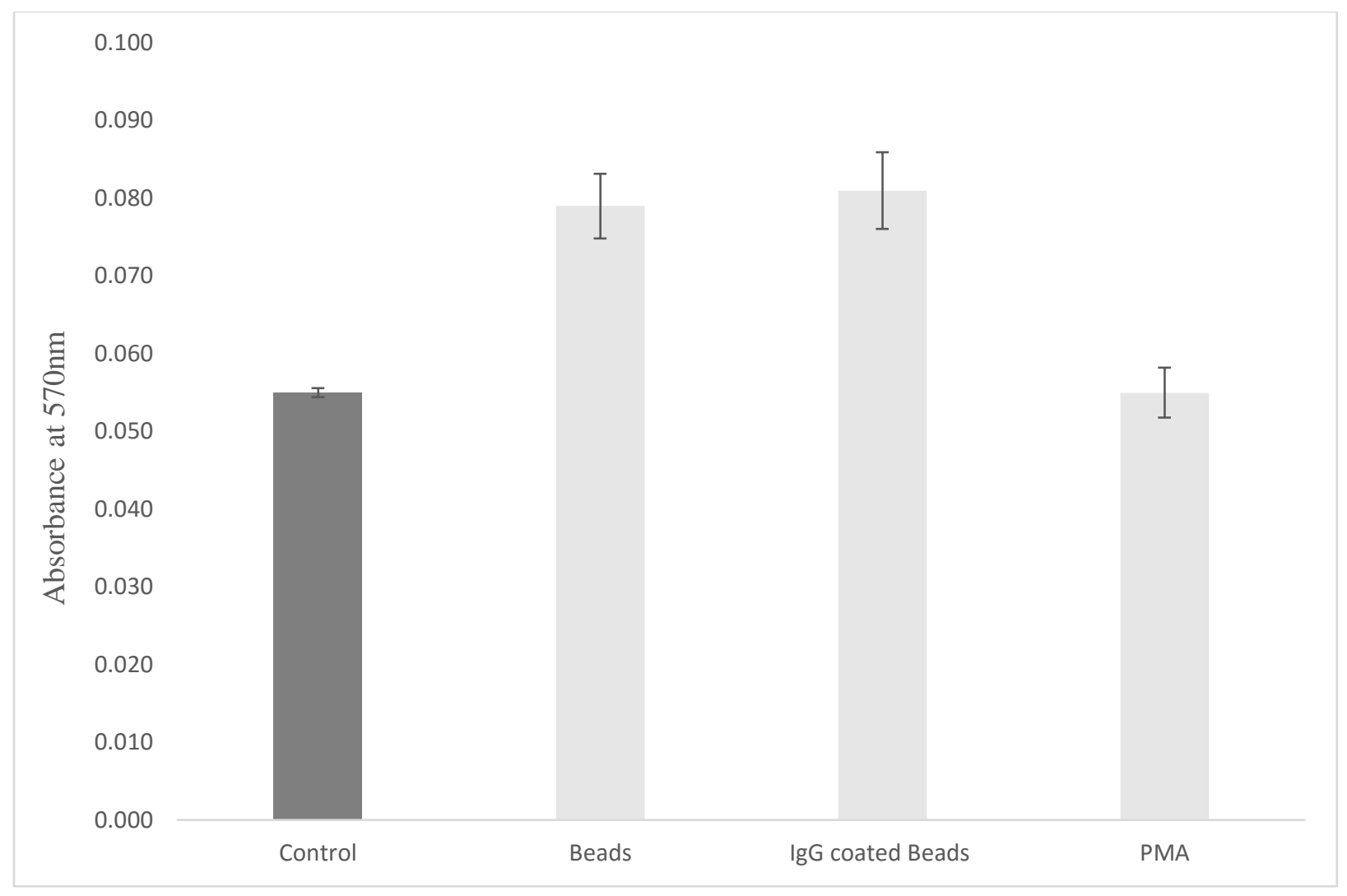

Figure 3.4 A colorimetric cellular HRP assay measured by UV/Vis spectrometry. The production of $\mathrm{H}_{2} \mathrm{O}_{2}$ (ROS) by RAW 264.7 macrophages in response to ligand coated beads was measured by an enzyme linked cellular assay where the substrate Amplex red (AR) and the enzyme Horse radish peroxidase (HRP) were exogenously supplied to yield resorufin in a $\mathrm{H}_{2} \mathrm{O}_{2}$ dependent reaction. The reaction mixture contained $10 \mathrm{ng} / \mathrm{ml}$ of $\mathrm{HRP}$ and $0.1 \mathrm{mM}$ of $\mathrm{AR}$ in isotonic experimental media with different conditions: melanin beads, IgG coated beads and $1 \mu \mathrm{M}$ PMA. The plate was read on the microplate fluorimeter at $570 \mathrm{~nm}$ after $30 \mathrm{~min}$ of incubation by transferring $200 \mu \mathrm{L}$ of supernatants into 96 wells. Each data point was representative of three experiments. 


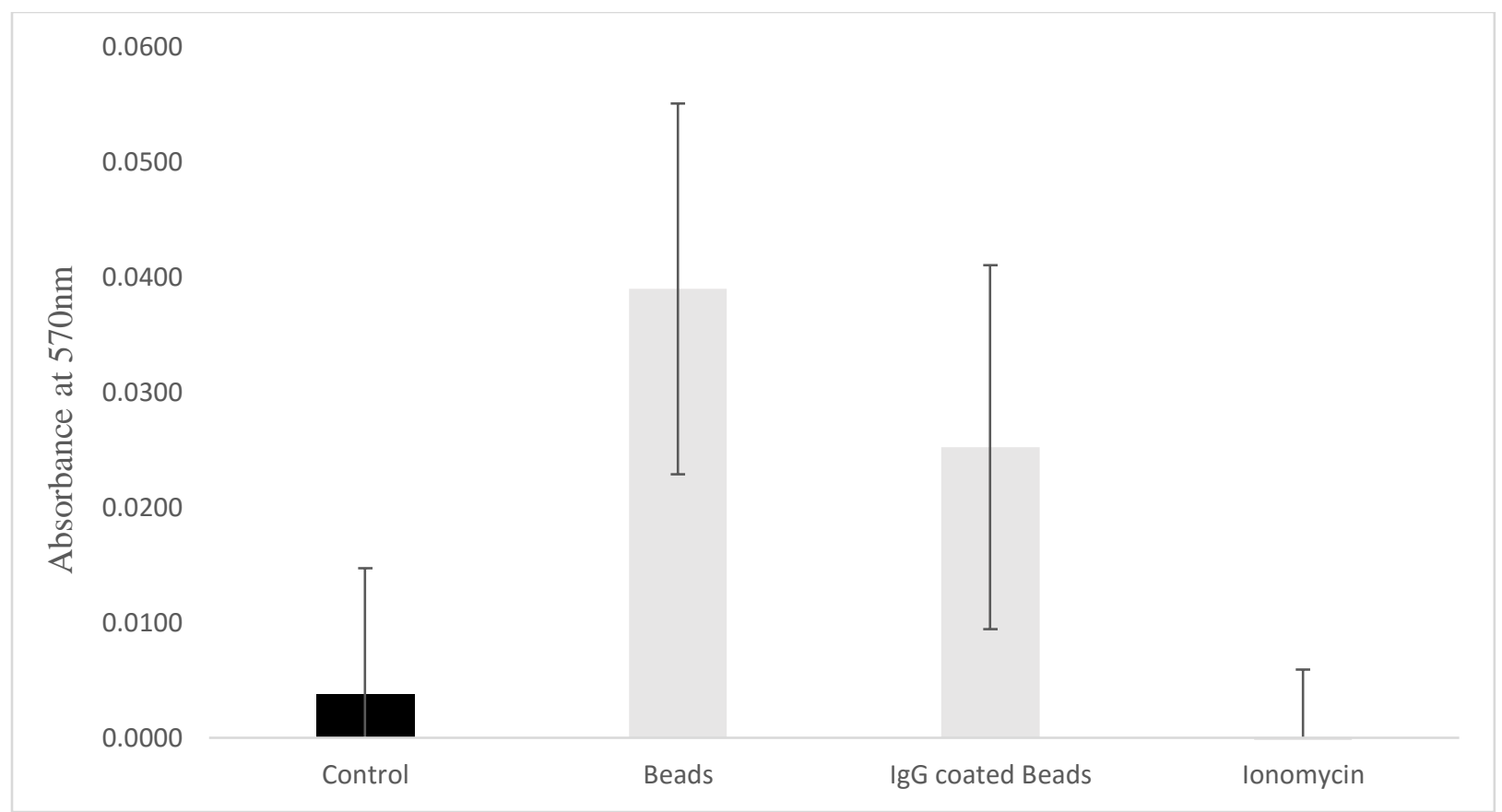

Figure 3.5 A colorimetric cellular HRP assay measured by UV/Vis spectrometry. The yield of resorufin in a $\mathrm{H}_{2} \mathrm{O}_{2}$ dependent reaction by RAW cells in response to ligand coated beads and ionomycin in the presence of Amplex Red (AR) and the enzyme Horse radish peroxidase (HRP). The reaction mixture contained 10ng/ml of HRP and $0.1 \mathrm{mM}$ of AR in isotonic experimental media with different conditions: Beads, IgG coated beads and $2 \mu \mathrm{M}$ ionomycin. The plate was read on the microplate fluorimeter at $570 \mathrm{~nm}$ after $15 \mathrm{~min}$ of incubation by transferring $200 \mu \mathrm{L}$ of supernatants into 96 wells. Computed mean of blank+3SD was 0.121 when $\mathrm{N}=4$. Absorbance of each treatment was lower than 0.121 indicated that it is not above LOQ. 


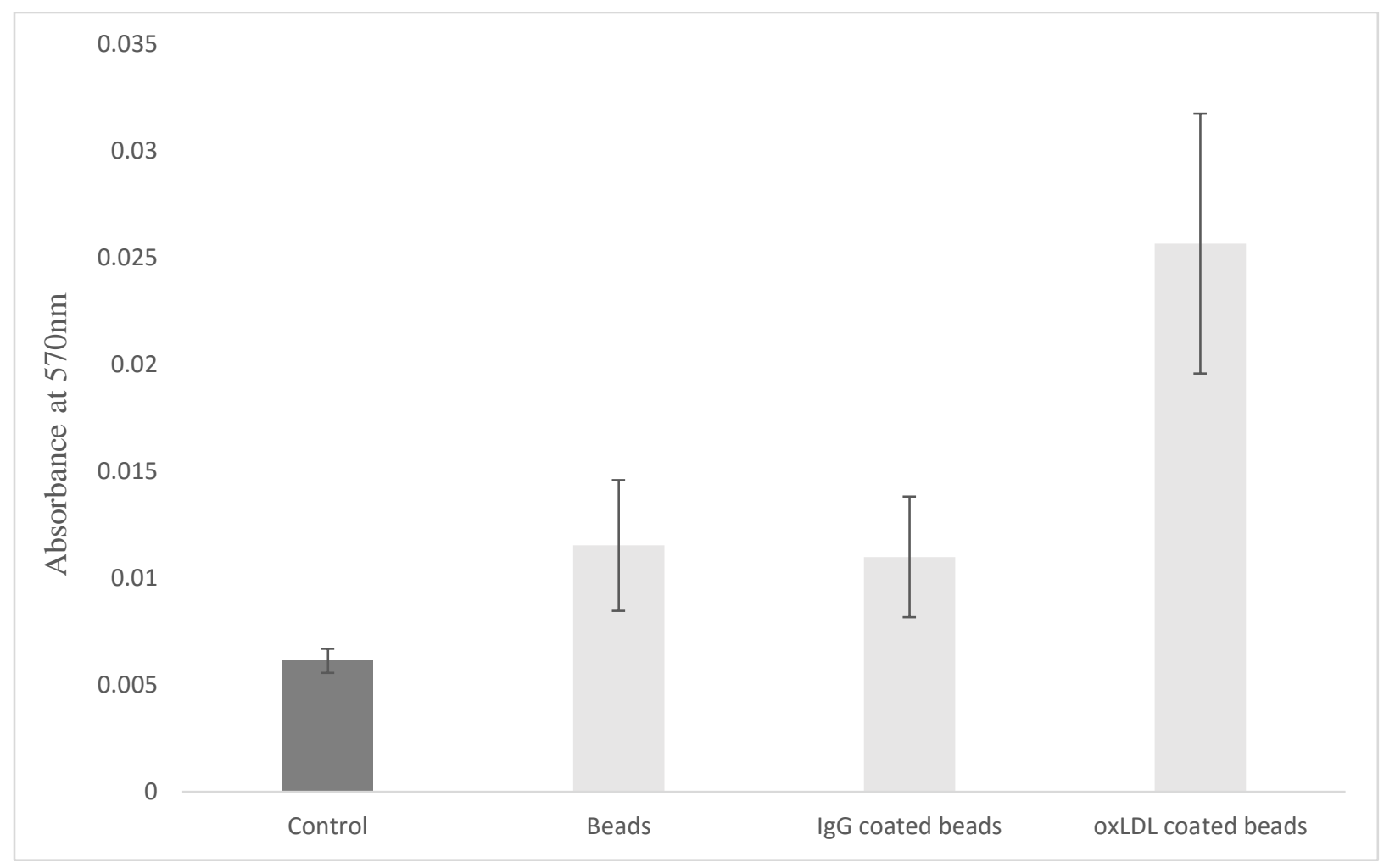

Figure 3.6 A colorimetric cellular HRP assay measured by UV/Vis spectrometry. The yield of resorufin in a $\mathrm{H}_{2} \mathrm{O}_{2}$ dependent reaction by RAW cells in response to different ligand coated beads in the presence of Amplex Red (AR) and the enzyme Horse Radish Peroxidase (HRP). The reaction mixture contained $10 \mathrm{ng} / \mathrm{ml}$ of $\mathrm{HRP}$ and $0.1 \mathrm{mM}$ of $\mathrm{AR}$ were exogenously added to the isotonic experimental media were different conditions to measured production of resorufin. The plate was read on the microplate fluorimeter at $570 \mathrm{~nm}$ after $30 \mathrm{~min}$ of incubation by transferring $200 \mu \mathrm{L}$ of supernatants into 96 wells. Each data point was representative of five independent experiments. (Mean of blank+3SD=0.0469, N=5). Each treatment was not above the LOQ. 


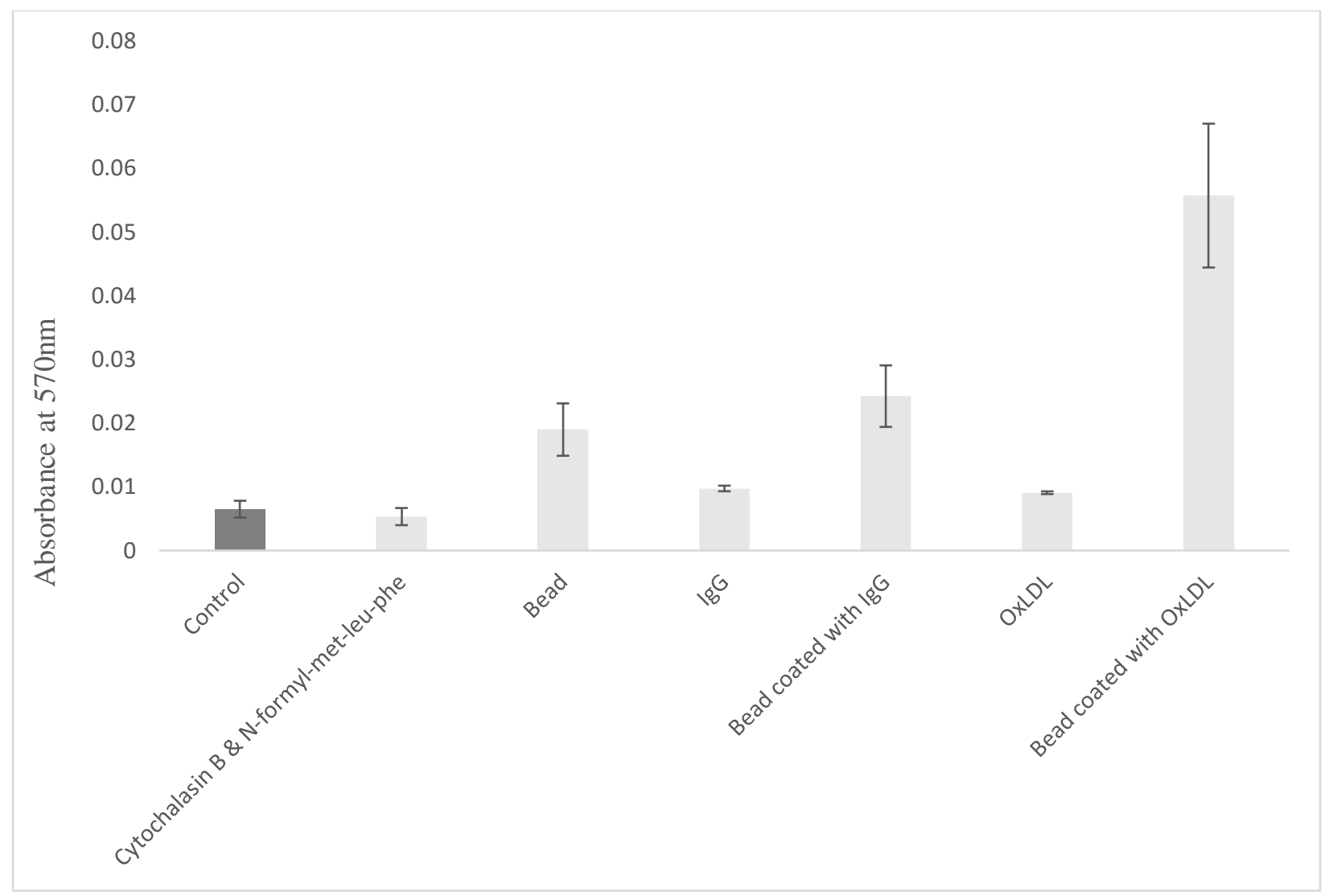

Figure 3.7 Production of resorufin from the activation of the macrophage respiratory burst measured by enzyme-catalyzed oxidation of AR assay. Ten $\mathrm{ng} / \mathrm{ml}$ of $\mathrm{HRP}$ and $0.1 \mathrm{mM}$ of AR in isotonic experimental media with different conditions. The plate was read on the microplate fluorimeter at $570 \mathrm{~nm}$ after $30 \mathrm{~min}$ of incubation by transferring $200 \mu \mathrm{L}$ of supernatants into 96 wells. Each data point was representative of four independent experiments. Average absorbance was corrected by subtracting from the average absorbance of blank (Mean of blank $+3 \mathrm{SD}=0.0485$ ). 


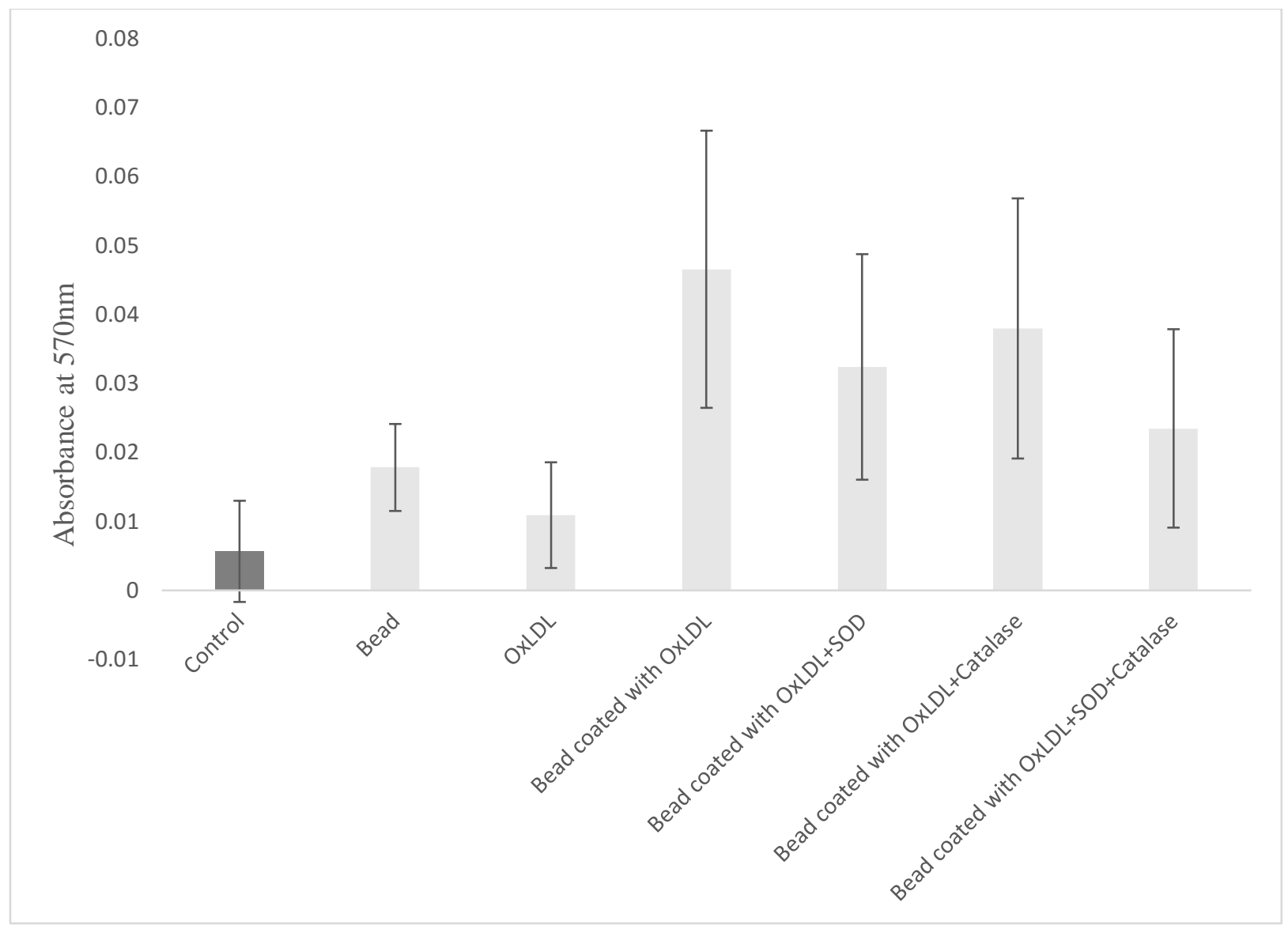

Figure 3.8 A cellular HRP assay measured effect of beads coated oxLDL on antioxidant enzymes were measured by UV/Vis absorbance at $570 \mathrm{~nm}$. The reaction mixture contained 10 $\mathrm{ng} / \mathrm{ml}$ of HRP and $0.1 \mathrm{mM}$ of AR were exogenously added to the isotonic experimental media were different conditions to measured production of resorufin. Catalase (1000 units/ml) and SOD (500 units $/ \mathrm{ml}$ ) was incubated $30 \mathrm{~min}$ prior to addition of $0.1 \mathrm{mM} \mathrm{AR}$ and $10 \mathrm{ng} / \mathrm{ml}$ of HRP. The plate was read on the microplate fluorimeter at $570 \mathrm{~nm}$ after $30 \mathrm{~min}$ of incubation by transferring $200 \mu \mathrm{L}$ of supernatants into 96 wells. Each data point was representative of four independent experiments. (Mean of blank $+3 \mathrm{SD}=0.0637, \mathrm{~N}=4$ ) 


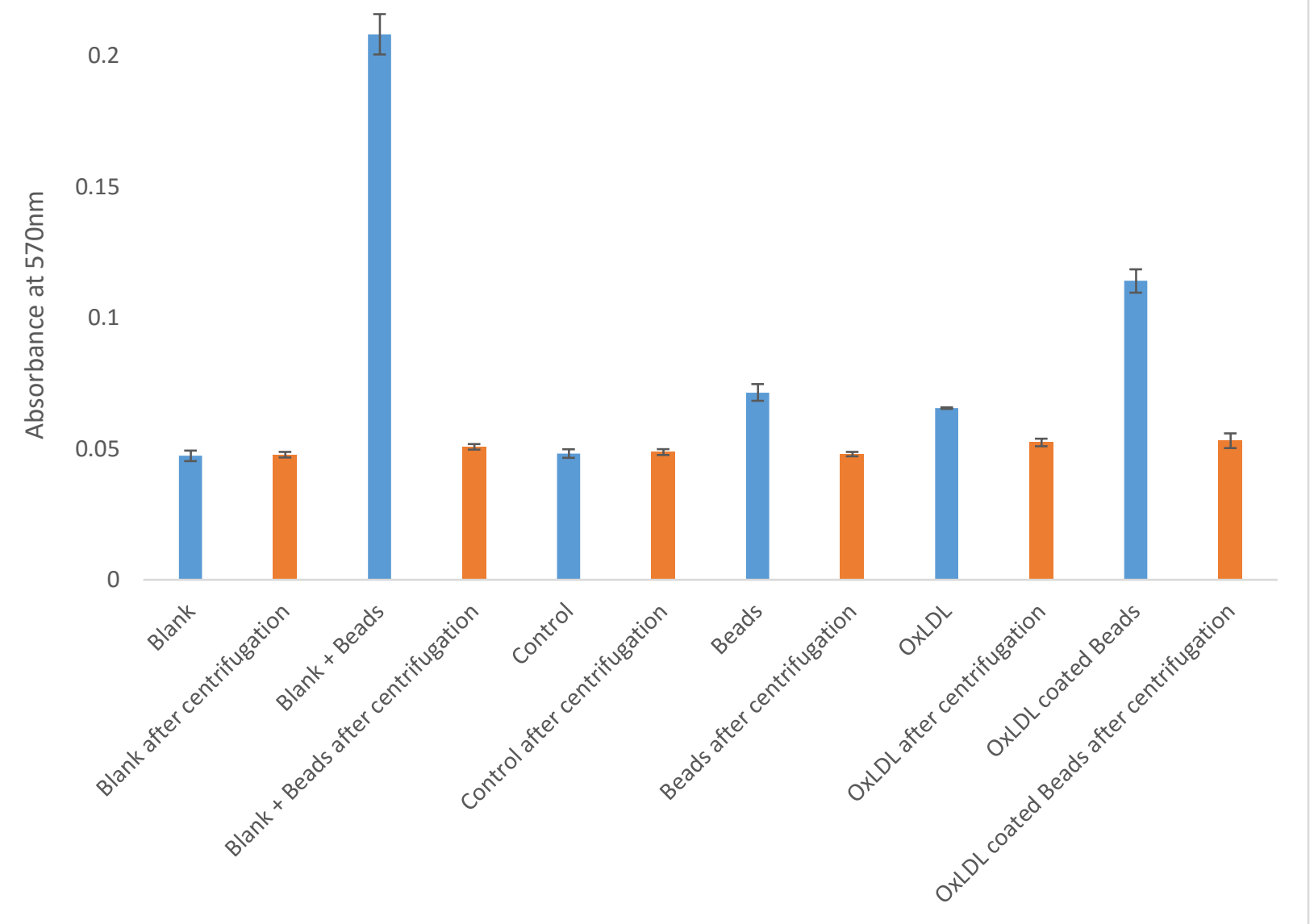

Figure 3.9 To test enzyme-catalyzed oxidation of AR using beads by measuring absorbance at $570 \mathrm{~nm}$. Cells were incubated on ice to reduce the production of $\mathrm{H}_{2} \mathrm{O}_{2}$ for $30 \mathrm{~min}$ after addition of each treatment. The plate was read on the microplate fluorimeter at $570 \mathrm{~nm}$ after $30 \mathrm{~min}$ of incubation by transferring $200 \mu \mathrm{L}$ of supernatants into 96 wells. After centrifugation at $14800 \mathrm{rpm}$ for $5 \mathrm{~min}$, absorbance has decreased compared to when supernatant was not centrifuged. To compare treatment between oxLDL coated beads and oxLDL coated Beads after centrifugation, paired sample t-test used $\left(\mathrm{p}=1.71972 \mathrm{E}^{-08}<0.05\right)$. Each data point was representative of three independent experiments. 


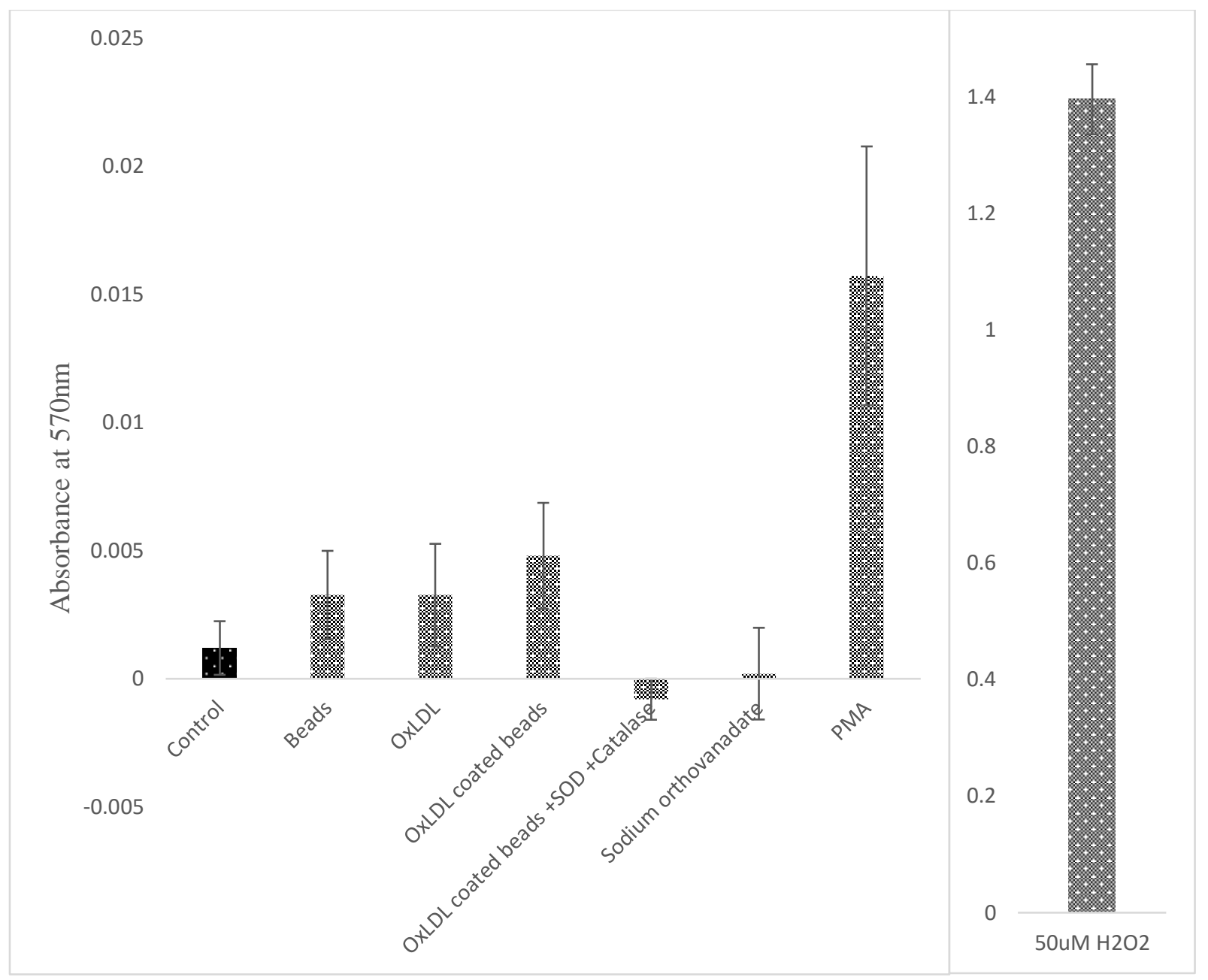

Figure 3.10 A hydrogen peroxide and reactive oxygen species cellular assay was measured by $\mathrm{UV} / \mathrm{V}$ is absorbance at $570 \mathrm{~nm}$. Ten $\mathrm{ng} / \mathrm{ml}$ of $\mathrm{HRP}$ and $0.1 \mathrm{mM}$ of $\mathrm{AR}$ in isotonic experimental media were incubated with ligand coated oxLDL for 30 minutes and PMA was incubated for 5 minutes. Catalase (1000 units/ml) and SOD (500 units/ml) were incubated 30 minutes prior to addition of $0.1 \mathrm{mM}$ AR and $10 \mathrm{ng} / \mathrm{ml}$ of HRP. The supernatant was centrifuged at $14800 \mathrm{rpm}$ for 5 minutes to remove excess melanin beads. Mean of absorbance in each treatment was plotted in bar graph. Each data point was representative of five independent experiments. (Mean of blank $+3 \mathrm{SD}=0.0574, \mathrm{~N}=5)$. One Way-ANOVA test resulted in $\mathrm{F}(5,83)=10.91, p=4.35 \mathrm{e}^{-0.85}$. Multy-way ANOVA test resulted in $\mathrm{F}(5,83)=10.911, \mathrm{p}=4.351 \mathrm{e}^{-08}$ Using $\mathrm{R}$. While the results are biologically significant, it was not above the LOQ. The confidence intervals using the Tukey method for each of the ten comparisons yields are shown Figure A. 1. 


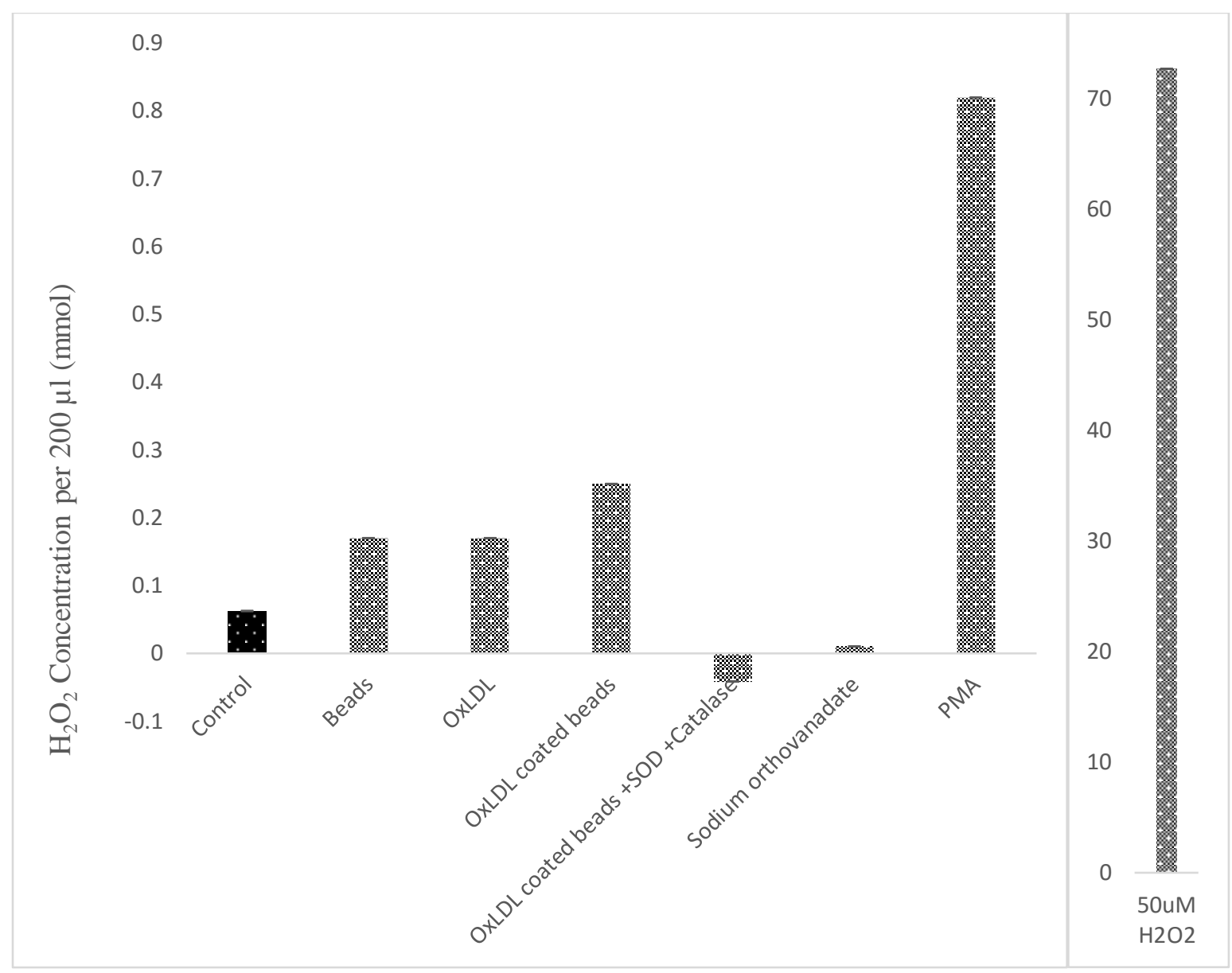

Figure 3.11 The production of $\mathrm{H}_{2} \mathrm{O}_{2}$ by RAW 264.7 macrophages in response to microbeads. Using the line of the best fit equation: $y=0.096 x+0.0187$ from the standard curve of $\mathrm{H}_{2} \mathrm{O}_{2}$, Figure 3.3, it was found that the mmol amount of $\mathrm{H}_{2} \mathrm{O}_{2}$ production in each treatment. 


\subsection{Determination of Optimal Conditions for ECL Experimentation}

Enhanced chemiluminescence (ECL) is simple and highly sensitive method to measure $\mathrm{H}_{2} \mathrm{O}_{2}$. To conduct an ECL experiment in order to investigate sensitivity compared to enzyme-catalyzed oxidation of AR assay, three different methods were compared to test the sensitivity of ECL measurement. When the ECL method was used, the lowest detection limit for $\mathrm{H}_{2} \mathrm{O}_{2}$ and $\mathrm{HRP}$ were $10 \mathrm{nmol}$ of $\mathrm{H}_{2} \mathrm{O}_{2}$ per $200 \mu \mathrm{L}$ and $2 \mathrm{ng} / \mathrm{ml} \mathrm{HRP}$ compared to Amplex red-HRP assay which allowed us to detect $0.2 \mathrm{nmol}$ of $\mathrm{H}_{2} \mathrm{O}_{2}$ per $200 \mu \mathrm{L}$. The ECL method measured by Bio-Rad gel doc or BioTek microplate was not very sensitive. In addition, immobilize HRP was detected by the ECL method using PVDF and measured by Bio-Rad gel doc showed a much higher ECL signal. Up to $10 \mathrm{pg}$ of HRP could be detected, but using the ECL method only $0.1 \mathrm{mM} \mathrm{H}_{2} \mathrm{O}_{2}$ was detected (Figure 3.15). The ECL method is a simple and sensitive method to measure HRP in the presence of excess $\mathrm{H}_{2} \mathrm{O}_{2}$ but was not sensitive at low concentrations of hydrogen peroxide. 


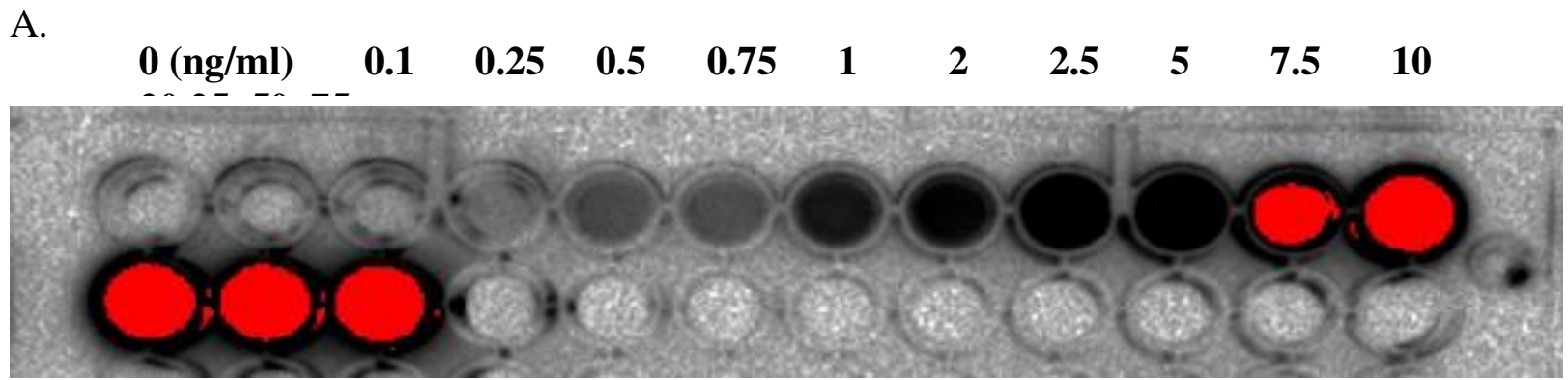

$25 \quad 50 \quad 75$

B.

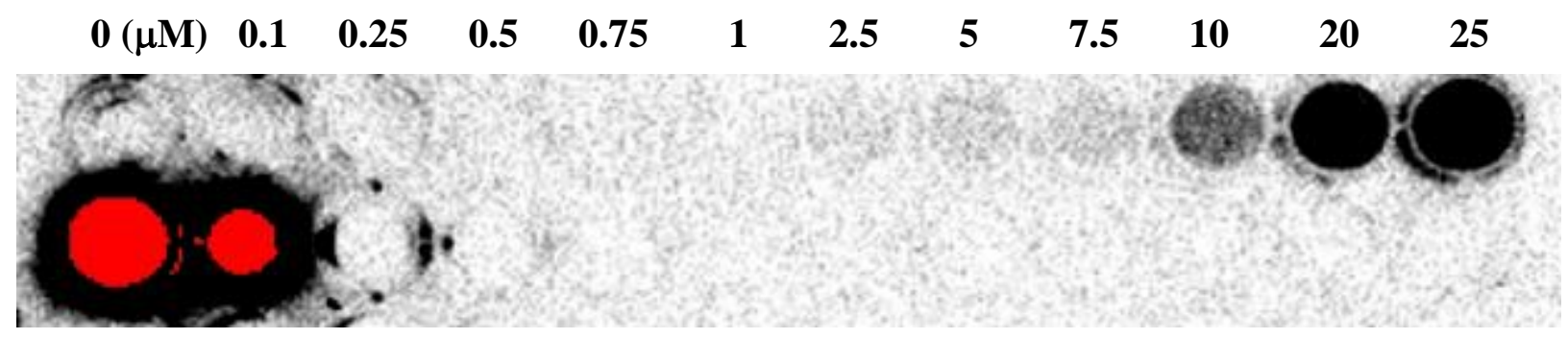

$75 \quad 100$

C.

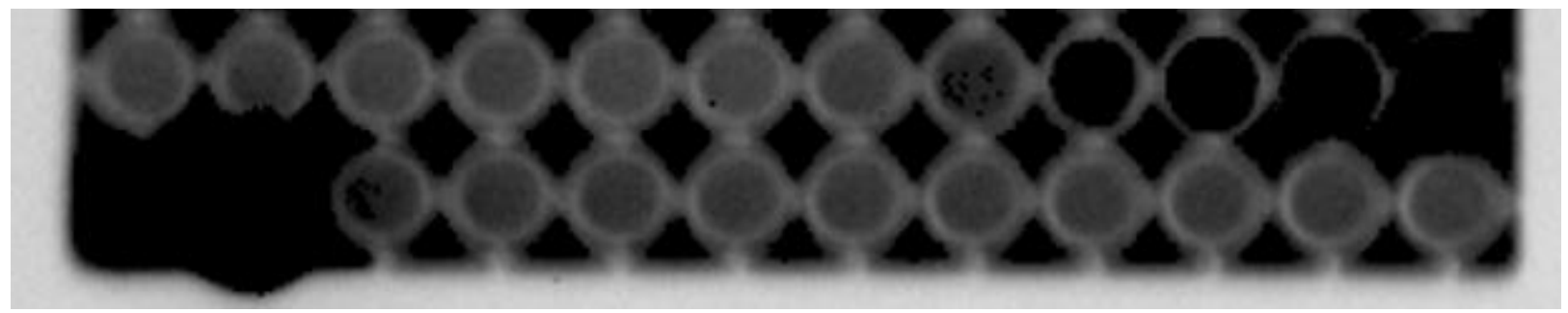

Figure 3.12 The detection of HRP and $\mathrm{H}_{2} \mathrm{O}_{2}$ using the ECL method. Panels: A, HRP standard curves in vitro reaction when HRP concentration responses up to $0.5 \mathrm{ng} / \mathrm{ml}$ in total volume of 200 $\mu \mathrm{L}$, with presence of $100 \mathrm{mM}$ Tris- $\mathrm{HCl}, 1.25 \mathrm{mM}$ Luminol, and $2 \mathrm{mM} 4-\mathrm{IPBA}$ and $5.3 \mathrm{mM} \mathrm{H}_{2} \mathrm{O}_{2}$. Each well indicates $\mathrm{ng} / \mathrm{ml}$ of HRP respectively; 0, 0.1, 0.25, 0.5, 0.75, 1, 2, 2.5, 5, 7.5, 10, 20, 25, 50,$75 ; \mathrm{B}$, the $\mathrm{H}_{2} \mathrm{O}_{2}$ standard curve in the $10 \mathrm{ng} / \mathrm{ml} \mathrm{HRP,} 100 \mathrm{mM}$ Tris- $\mathrm{HCl}, 1.25 \mathrm{mM}$ Luminol, and $2 \mathrm{mM}$ 4-IPBA. With $\mu \mathrm{M}$ of $\mathrm{H}_{2} \mathrm{O}_{2}$ respectively; $0,0.1,0.25,0.75,1,2.5,5,7.5,10,25,50,75$, 100 ; C, indicated the same procedures as B but, with different concentration of $\mathrm{H}_{2} \mathrm{O}_{2}$ in HighBinding 96 well plates to be measured by Bio-Rad geldoc. 


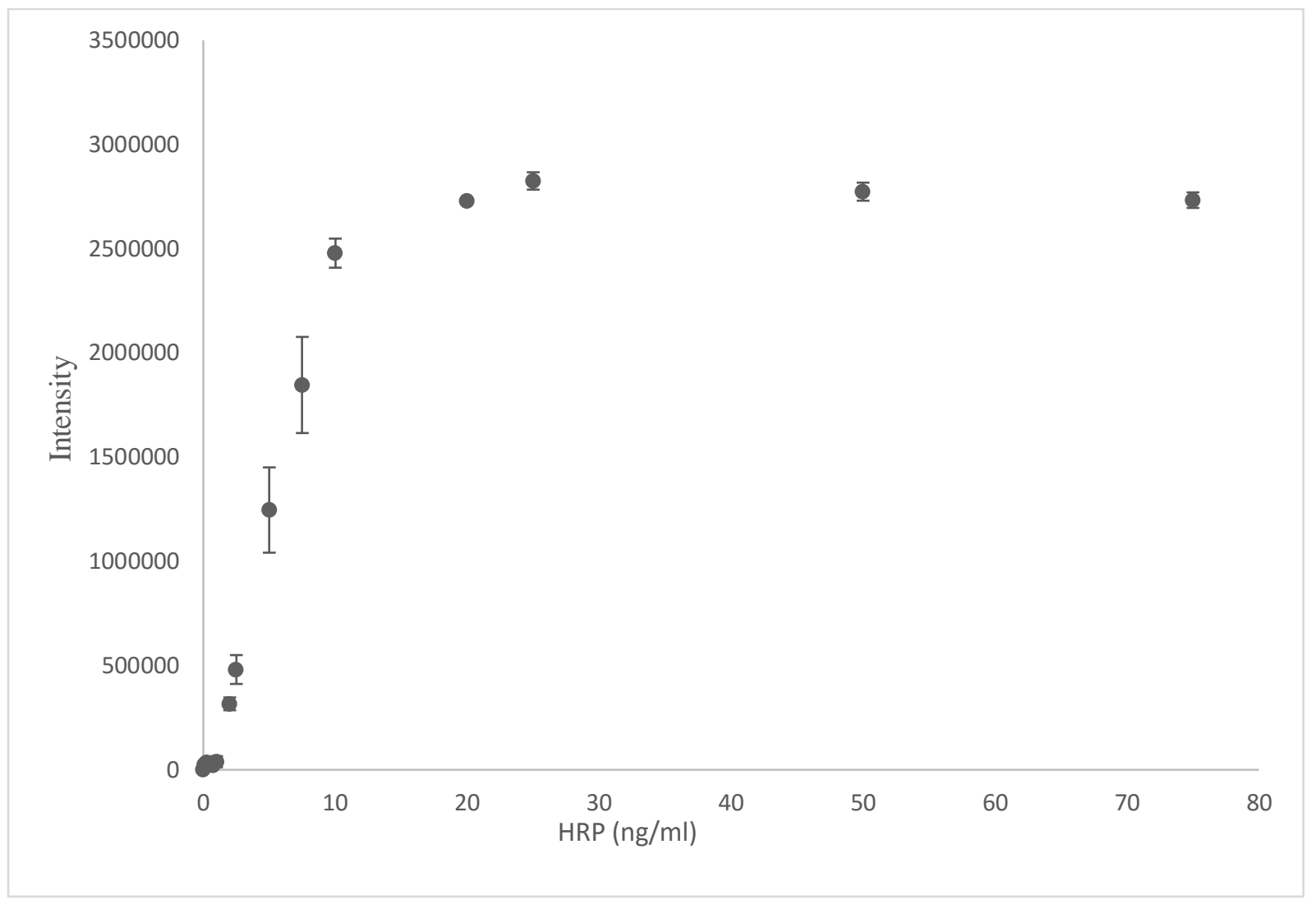

Figure 3.13 The image analysis of the HRP standard curves quantified using Image Lab software (see Figure 3.12.A). HRP standard curves in vitro reaction with presence of $100 \mathrm{mM}$ Tris- $\mathrm{HCl}, 1.25 \mathrm{mM}$ Luminol, and $2 \mathrm{mM}$ 4-IPBA and $5.3 \mathrm{mM} \mathrm{H}_{2} \mathrm{O}_{2}$. As little as $0.1 \mathrm{ng} / \mathrm{ml}$ of HRP can be detected but LOQ was $0.75 \mathrm{ng} / \mathrm{ml}$ (Mean of Blank+3SD=6611.97). After $10 \mathrm{ng} / \mathrm{ml}$ of HRP, pixel intensity was fully saturated. Each data point was representative of three experiments and some of the error bars are not visible due to small deviations. 


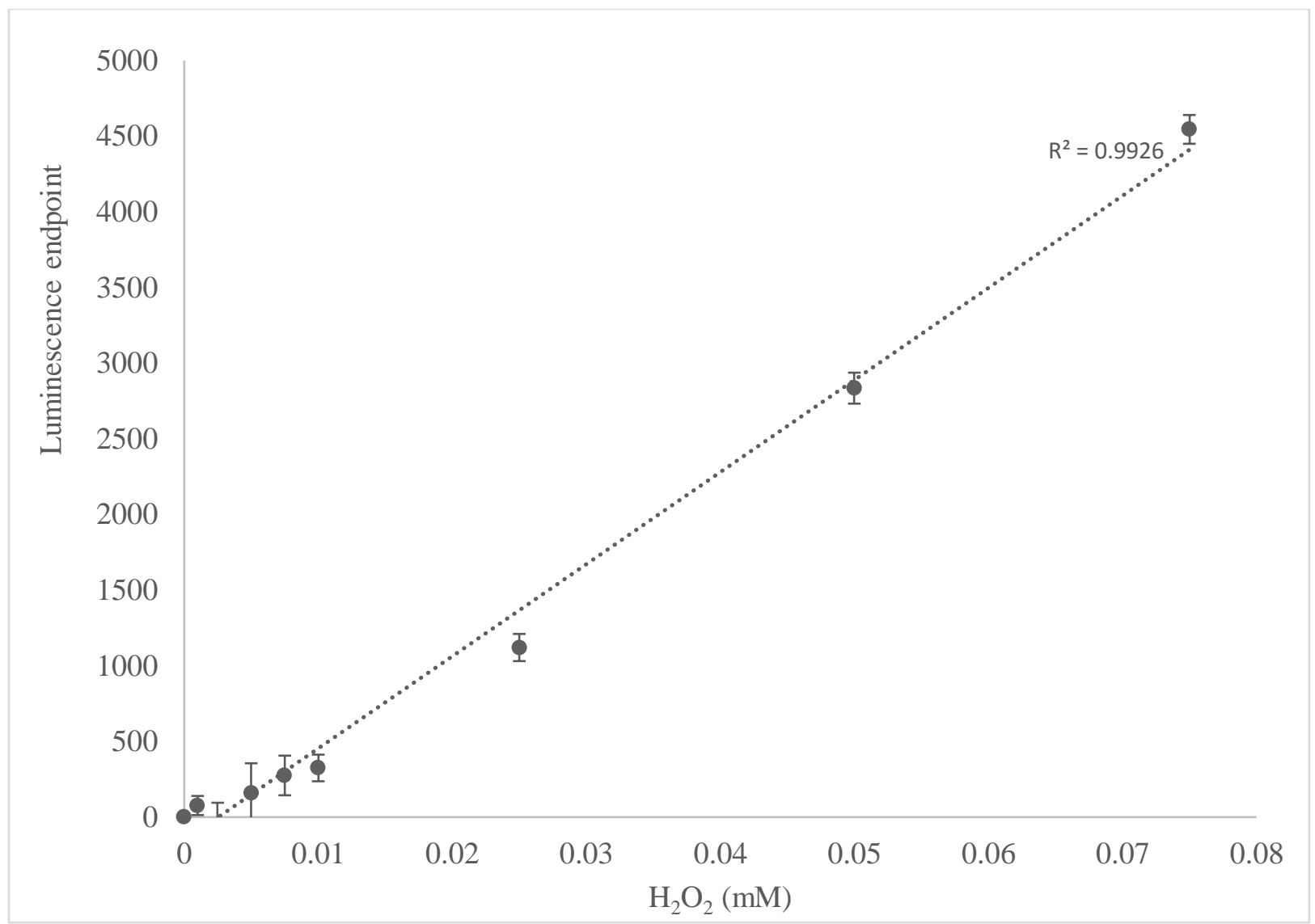

Figure 3.14 The oxidation of luminol in the presence of increasing $\mathrm{H}_{2} \mathrm{O}_{2}$ was measured by Bio-Tek microplate reader. In vitro reaction with presence of $100 \mathrm{mM}$ Tris- $\mathrm{HCl}, 1.25 \mathrm{mM}$ Luminol, and $2 \mathrm{mM}$ 4-IPBA and $5.3 \mathrm{mM} \mathrm{H}_{2} \mathrm{O}_{2}$. Enhanced chemiluminescent was tested to measure the LOD for $\mathrm{H}_{2} \mathrm{O}_{2}$. Luminol was oxidized by $\mathrm{HRP}$ using $\mathrm{H}_{2} \mathrm{O}_{2}$ in $1: 1$ stoichiometric to produce aminophthalate with light emission detectable to $0.2 \mathrm{nmol}$ level. The LOD for $\mathrm{H}_{2} \mathrm{O}_{2}$ using ECL was $10 \mathrm{nmol}$ of $\mathrm{H}_{2} \mathrm{O}_{2}$ per $200 \mu \mathrm{l}$ (Mean of blank+3SD=1436.08). Each data point was representative of three experiments and some of the error bars are not visible due to small deviations. The ECL method was not judged to be significantly better than UV/Vis. 
A.

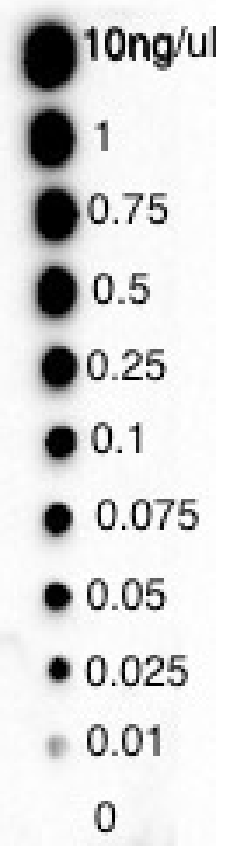

B.

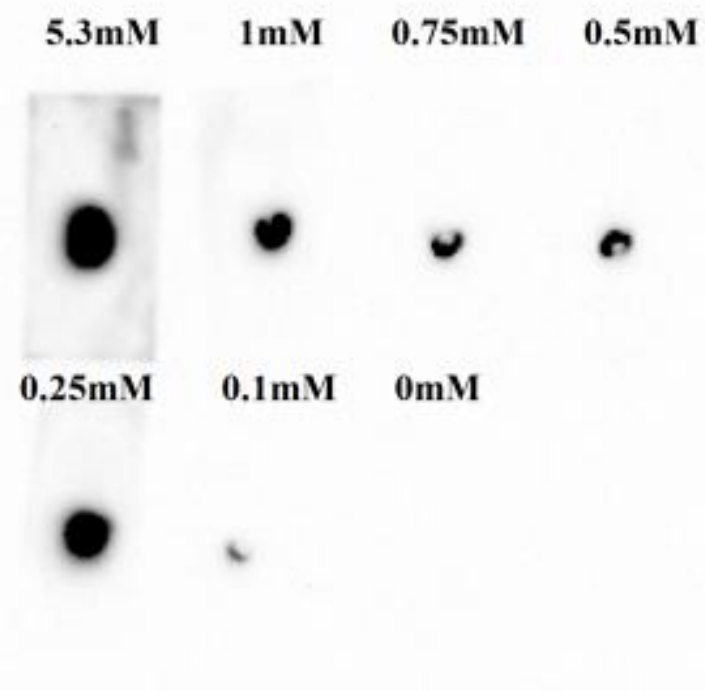

Figure 3.15 The ECL reaction measured on methanol activated PVDF with increasing HRP and $\mathrm{H}_{2} \mathrm{O}_{2}$. Different concentration of $\mathrm{HRP}$ and $\mathrm{H}_{2} \mathrm{O}_{2}$ onto methanol-activated PVDF with detection by gel doc after a minute incubation in ECL solution $\left(5.3 \mathrm{mM} \mathrm{H} \mathrm{O}_{2}, 1.25 \mathrm{mM}\right.$ luminol, and $2.5 \mathrm{mM}$ enhancing agent of 4-iodophenylboronic acid in total volume of $1 \mathrm{ml}$ ). Panel; A, the dilution curve of HRP showed that as little as $0.1 \mathrm{ng} / \mu \mathrm{l}$ can be detected. Panel; $\mathrm{B}$, the dilution curve of $\mathrm{H}_{2} \mathrm{O}_{2}$ showed the sensitivity of $0.1 \mathrm{mM}$. 


\subsection{Detection of $\mathrm{H}_{2} \mathrm{O}_{2}$ production in $\mathrm{RAW} 264.7$ using LC-ESI-MS}

To determine the sensitivity of resorufin, the liquid chromatography with electrospray ionization and mass spectrometry (LC-ESI-MS) at $214 \mathrm{~m} / \mathrm{z}[\mathrm{M}+\mathrm{H}]$ was used. The concentration of resorufin from $0 \mathrm{nM}$ or from $100 \mathrm{nM}$ to $10 \mu \mathrm{M}$ was injected through a $2 \mu \mathrm{L}$ loop into a mobile phase of $70 \%$ acetonitrile and $30 \%$ water to a final concentration of $0.1 \%$ acetic acid as the ionization buffer flowing at $10 \mu \mathrm{L}$ per minute at $5 \mathrm{kV}$ over $15 \mathrm{~cm}$ and $300 \mu \mathrm{m}$ ID normal phase (300Å) column. LC-ESI-MS allowed for the detection of 0.2 pmol amounts of resorufin (

Figure 3.16). Relative abundance computed to obtain the line of the best fit $(y=6939.9 x+602.91$, $\mathrm{R}^{2}=0.997$ ) and the LOQ was $0.2 \mathrm{pmol}$ (Blank of mean $+3 \mathrm{SD}=2.53 \mathrm{E}+04$ ) (Figure 3.17). In order to avoid an extra step of ziptipping for sample clean-up, EtOH extraction was tested and showed that resorufin recovery was less than 50\% (Figure 3.18). Before injecting resorufin from cellular media into LC-ESI-MS, resorufin was collected using a ziptip. A $1 \mathrm{ml}$ volume of $0.1 \mathrm{mM}$ AR reacted with $\mathrm{H}_{2} \mathrm{O}_{2}$ at a stoichiometry $1: 1$ with $10 \mathrm{ng} / \mathrm{ml}$ of $\mathrm{HRP}$ to yield the oxidation product, resorufin. The yield of resorufin in an $\mathrm{H}_{2} \mathrm{O}_{2}$ dependent reaction by RAW cells in response to different ligand coated beads in the presence of Amplex Red (AR) and the enzyme Horse Radish Peroxidase (HRP). To concentrate and desalted the resorufin from the supernatant, $200 \mu \mathrm{L}$ of supernatant was ziptipped and $2 \mu 1$ of eluent were diluted 10 folds and in injected via a $20 \mu \mathrm{L}$ loop for analysis by LCESI-MS (Figure 3.20). The relative abundance shown by bar graph and blank of mean +3 SD was 479,240 and the treatments were not above the LOQ. One Way-ANOVA resulted in $\mathrm{F}(6,21)=1.969$, $p=0.116$. Multy-way ANOVA resulted in $\mathrm{F}(6,21)=1.969, p=0.1163$ using $\mathrm{R}$ (Figure 3.21). Relative abundance computed to bar graph by using the line of the best fit generated from the resorufin standard curve and quantify the yield of resorufin in each treatment (Figure 3.22). 


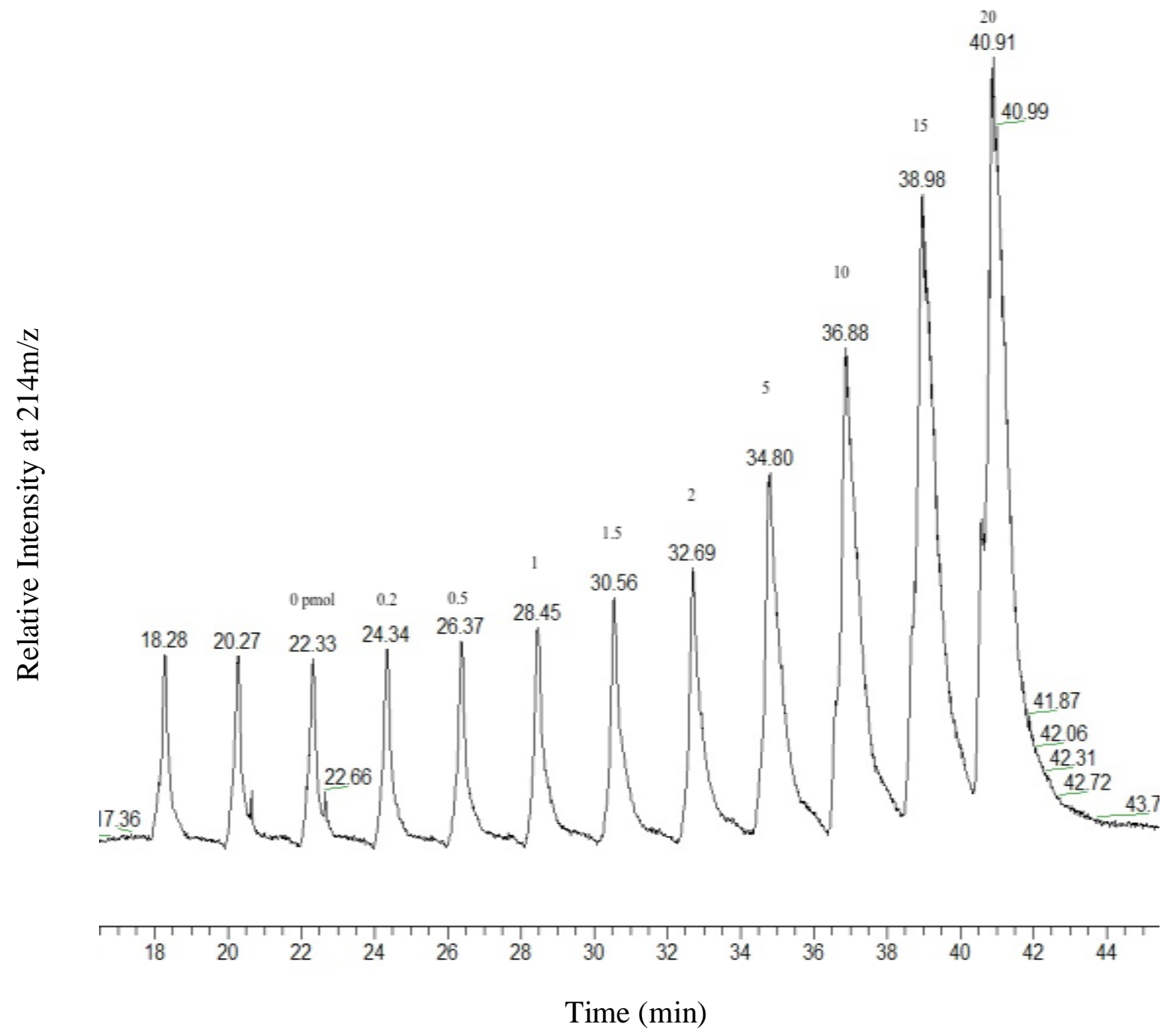

Figure 3.16 Standard curve of resorufin by liquid chromatography with electrospray ionization and mass spectrometry (LC-ESI-MS). Resorufin was detected by liquid chromatography with electrospray ionization and tandem mass spectrometry (LC-ESI-MS) at 214 $\mathrm{m} / \mathrm{z}[\mathrm{M}+\mathrm{H}]$. Each peak indicated pmol amount of resorufin and $\mathrm{y}$-axis was relative intensity while $\mathrm{x}$-axis was time. Total ion current trace of the open mass window. 


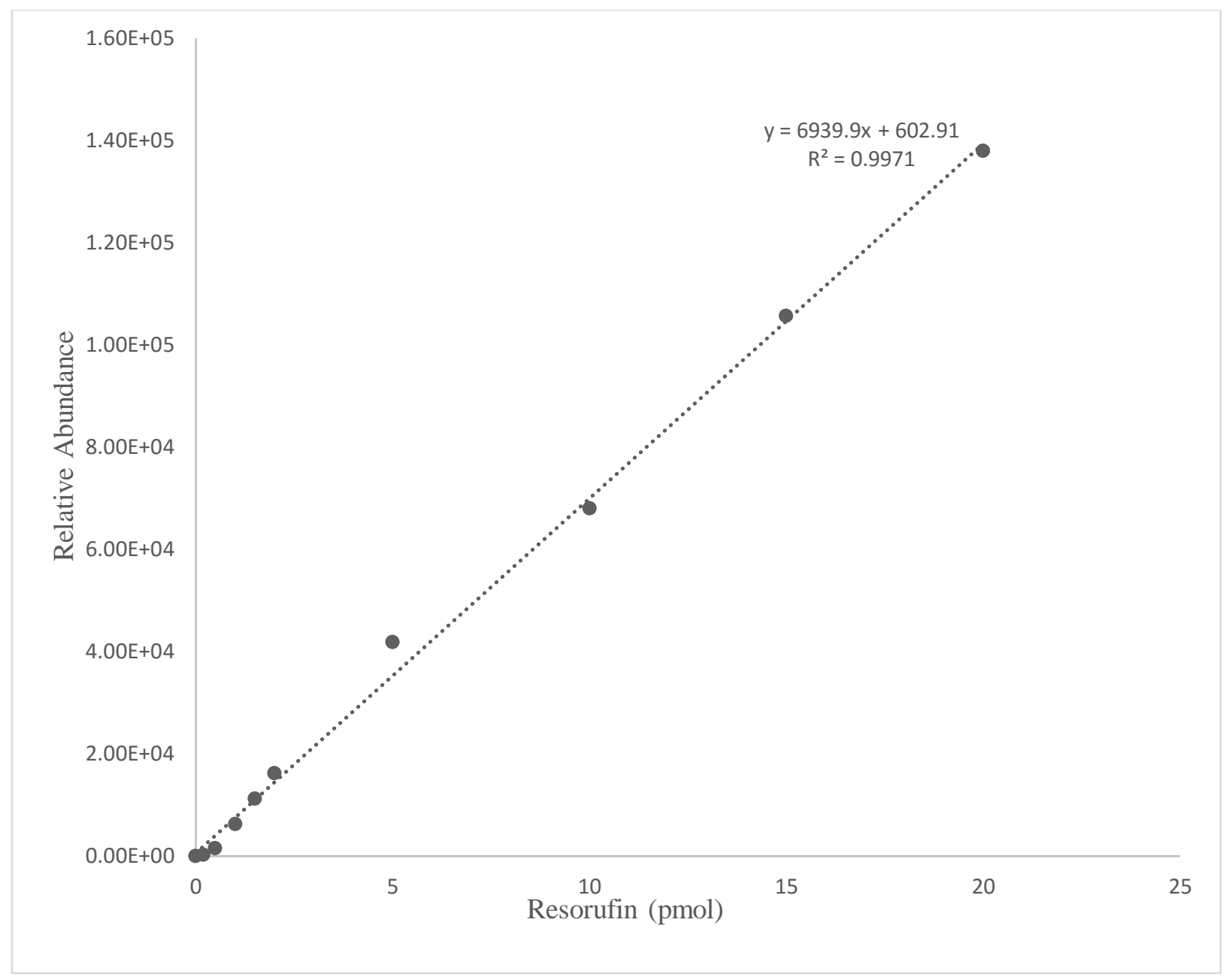

Figure 3.17 The Resorufin standard curve as measured by LC-ESI-MS. Different amount of increasing resorufin was injected and detected by liquid chromatography with electrospray ionization and mass spectrometry (LC-ESI-MS) at $214 \mathrm{~m} / \mathrm{z}[\mathrm{M}+\mathrm{H}]$. The lowest detection limit for resorufin was at 0.2 pmol while safe detection limit and quantification (LOQ) was 0.2 pmol as well $($ Mean of blank+3SD=2.53E+04). 

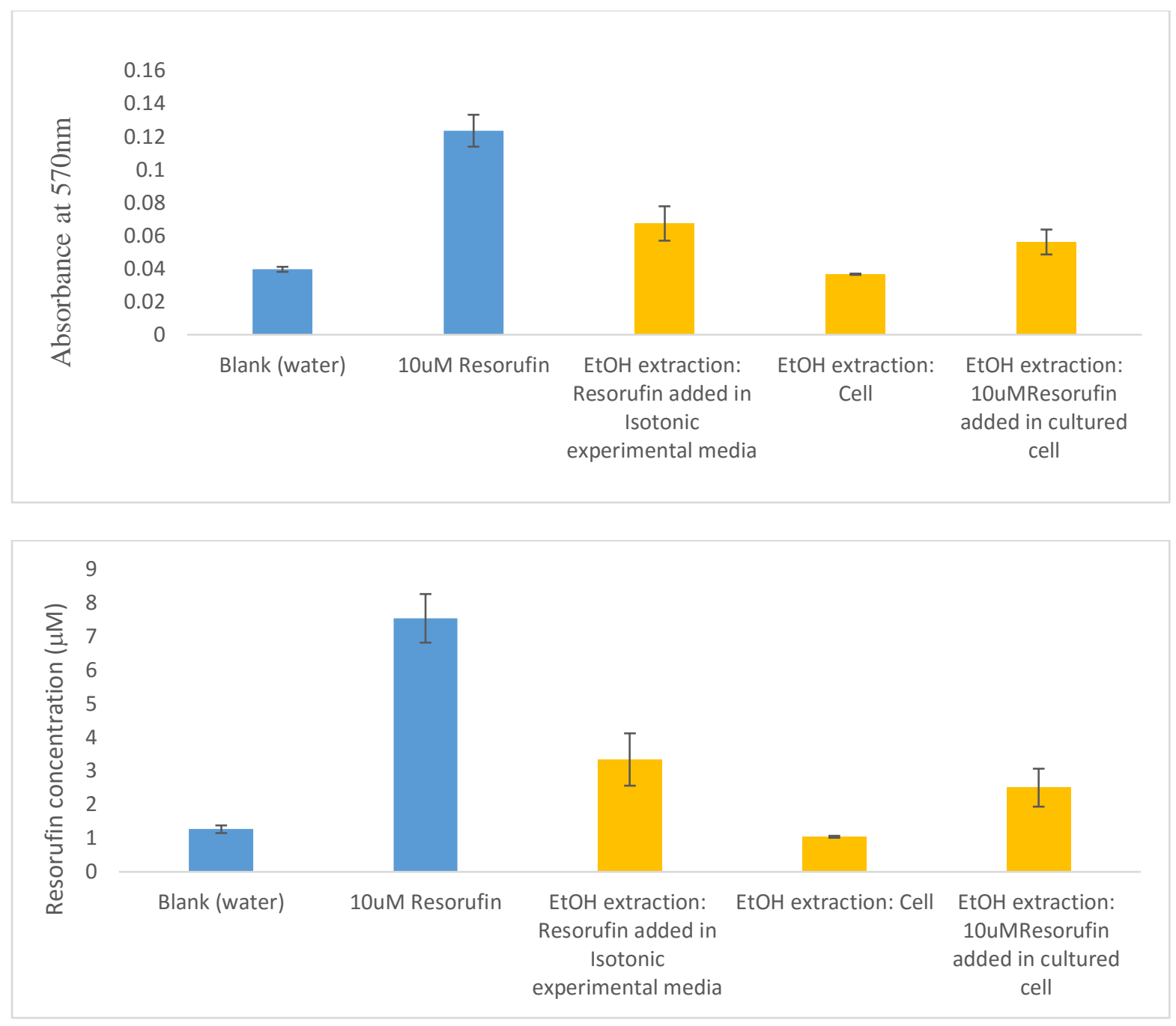

Figure 3.18 Resorufin recovery test using EtOH extraction. Cultured RAW 264.7 cells in 6 well for 48 hours and added isotonic experiment media (pH 7.4). $10 \mu \mathrm{M}$ of resorufin was incubated for 30 minutes at $37^{\circ} \mathrm{C}$. Total $1 \mathrm{ml}$ of each sample was dried using a speed-vac to vacuum dry to remove solvent and leave resorufin. One $\mathrm{ml}$ of $\mathrm{EtOH}$ were added into fully dried samples and dried again. The same procedure was repeated for three times and $200 \mu \mathrm{L}$ was transferred to 96 wells to be measured by UV/Vis at $570 \mathrm{~nm}$. Resorufin recovery was less than $50 \%$. 


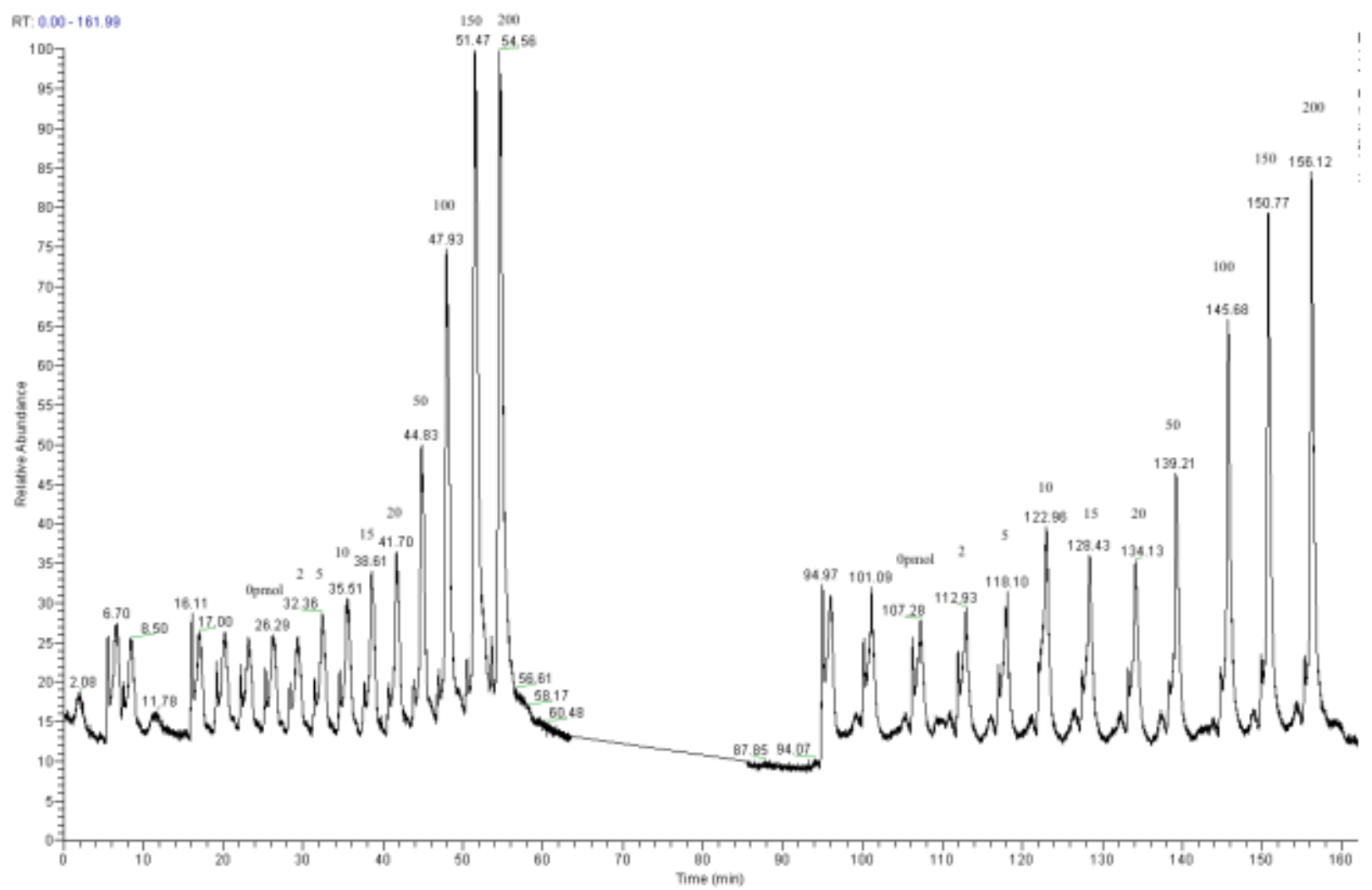

Figure 3.19 Resorufin recovery test: direct injection of resorufin versus zip-tiping $200 \mu \mathrm{l}$ of resorufin sample and detected by liquid chromatography with electrospray ionization and mass spectrometry (LC-ESI-MS). Different concentration of resorufin was injected through 20 $\mu l$ loop. Right side of resorufin standard curve was generated by ziptiping sample before injecting into $20 \mu$ l loop by a liquid chromatography with electrospray ionization and tandem mass spectrometry (LC-ESI-MS) at $214 \mathrm{~m} / \mathrm{z}[\mathrm{M}+\mathrm{H}]$. Each peak indicated pmol amount of resorufin and $\mathrm{y}$-axis was relative intensity while $\mathrm{x}$-axis was time. Total ion current trace of the open mass window 


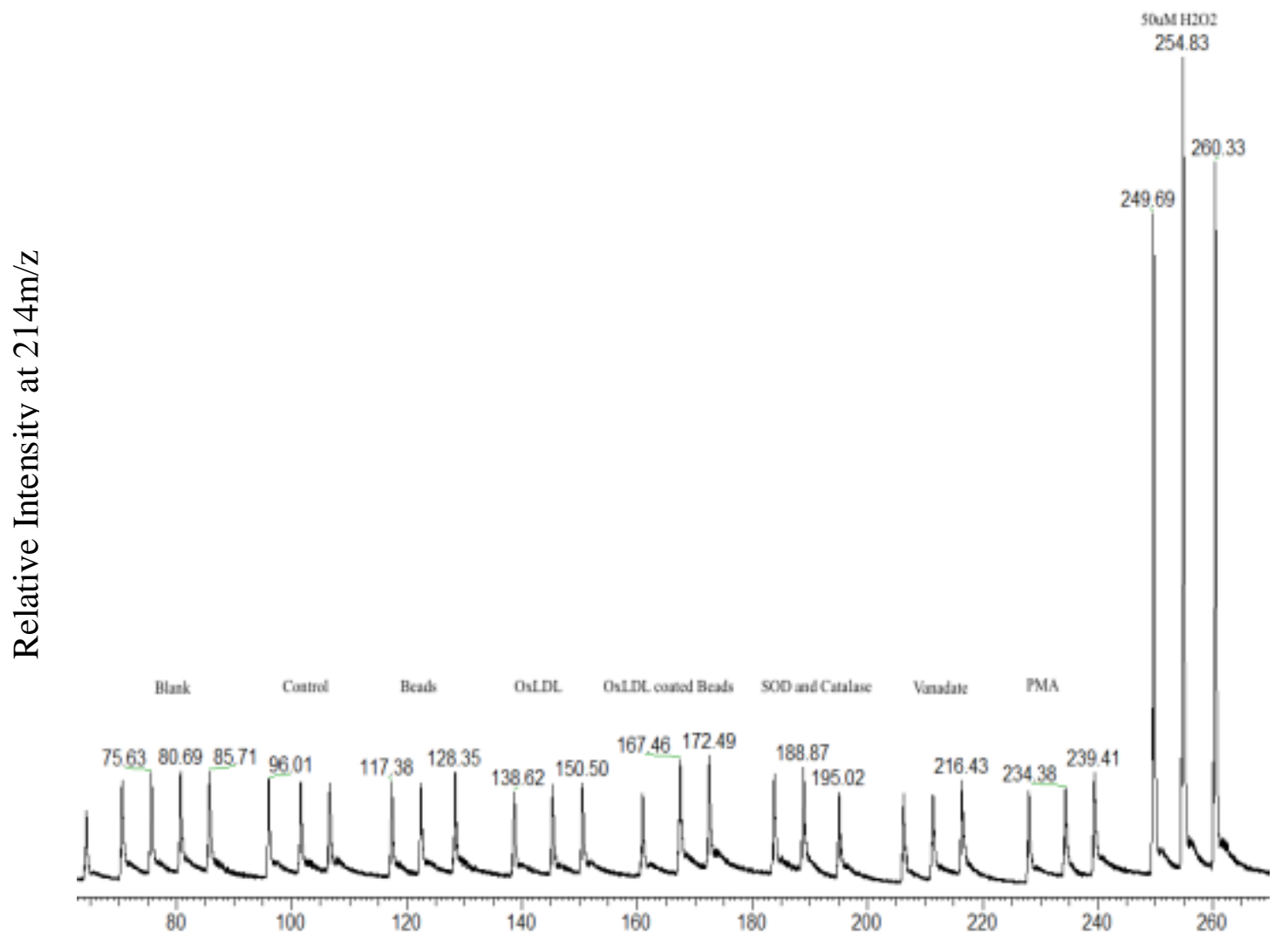

Time (min)

Figure 3.20 The production of $\mathrm{H}_{2} \mathrm{O}_{2}$ by Raw 264.7 cells in response to oxLDL coated beads and stimulator was measured by LC-ESI-MS. AR and HRP were exogenously supplied to yield resorufin in a $\mathrm{H}_{2} \mathrm{O}_{2}$ dependent reaction. To concentrate and desalted the resorufin from the $200 \mu \mathrm{L}$ of supernatant zip-tipped. Resorufin was detected by liquid chromatography with electrospray ionization and mass spectrometry (LC-ESI-MS) at $214 \mathrm{~m} / \mathrm{z}[\mathrm{M}+\mathrm{H}]$ by injecting through a $2 \mu \mathrm{L}$ loop into a mobile phase of $70 \%$ acetonitrile and $30 \%$ water to a final of $0.1 \%$ acetic acid as the ionization buffer flowing at $10 \mu \mathrm{L}$ per minute over $15 \mathrm{~cm}$ and $300 \mu \mathrm{m}$ ID normal phase $(300 \AA)$ column. First 5 peaks indicated Blank samples. Each three peaks indicated different treatments. 5min PMA 


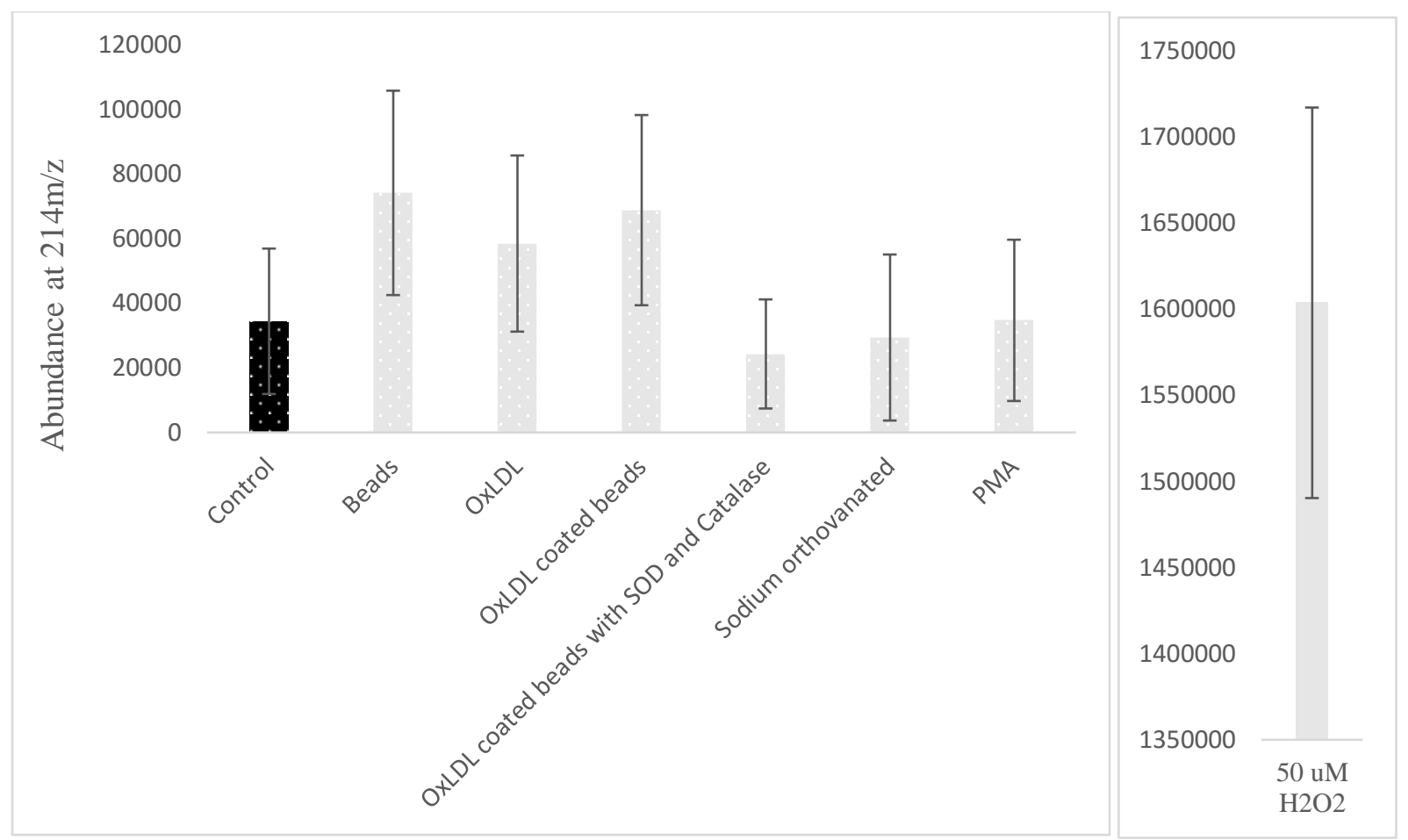

Figure 3.21 The production of $\mathrm{H}_{2} \mathrm{O}_{2}$ by Raw 264.7 cells in response to oxLDL coated beads and stimulator was measured by LC-ESI-MS was computed to bar graph using Figure 3.20. A total of $20 \mu \mathrm{L}$ or experimental media was concentrated and injected. Mean of blank+3SD was 479,23978 when $\mathrm{N}=4$. Although error is analytical but treatments were not above the LOQ. Using $\mathrm{R}$, One Way-ANOVA test resulted in $\mathrm{F}(6,21)=1.969, p=0.116$. Multy-way ANOVA test resulted in in $\mathrm{F}(6,21)=1.9686, p=0.1163$. Confidence intervals used the Tukey method for each of the ten comparisons yields are shown Figure A. 2. 


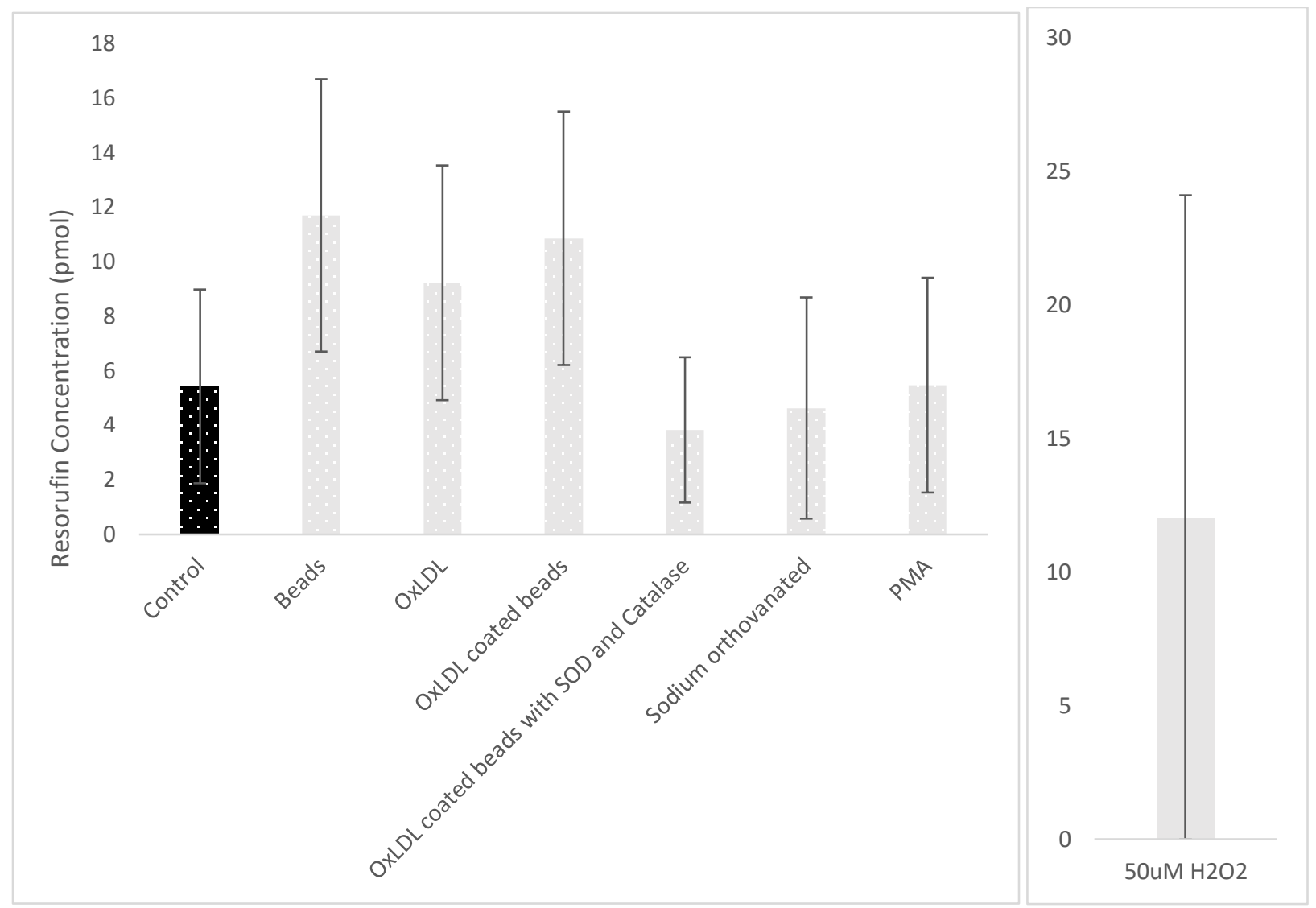

Figure 3.22 The production of $\mathrm{H}_{2} \mathrm{O}_{2}$ by Raw 264.7 cells in response to ligand coated beads and stimulator was measured by LC-ESI-MS calculated to find moles of resorufin using the resorufin standard curve (see Figure 3.17). A total of $20 \mu \mathrm{L}$ or experimental media was concentrated and injected. Using the equation: $y=6939.9 x+602.91$ from the standard curve of resorufin, and computed resorufin production in each treatment. 


\section{CHAPTER 4: DISCUSSION}

The aim of this research was to determine whether $\mathrm{H}_{2} \mathrm{O}_{2}$ in live cultured cells could be monitored by a combination of enzyme-linked $\mathrm{H}_{2} \mathrm{O}_{2}$ radical assay UV/Vis, ECL and LC-ESI-MS. An enzyme coupled reaction used the exogenous addition of the enzyme HRP and the substrate AR to detect trace amounts of $\mathrm{H}_{2} \mathrm{O}_{2}$ by macrophages during rest versus phagocytosis. In the presence of HRP, AR reacts with $\mathrm{H}_{2} \mathrm{O}_{2}$ in a 1:1 stoichiometric ratio to produce the red-fluorescent oxidation product, resorufin. The large amount of ROS produced by human neutrophils in response to N-fMLP or PMA may be measured by the oxidation of AR. Hence, the oxidation of AR by HRP should produce a direct measure of $\mathrm{H}_{2} \mathrm{O}_{2}$. Previous studies have shown that barely detectable amounts of $\mathrm{H}_{2} \mathrm{O}_{2}$ are produced by macrophages by the oxidation of AR. Five replicates of the experiment were conducted where PMA, Sodium Orthovanadate, and oxLDL coated beads were presented to RAW 264.7 cells to compare the mean absorbance at $570 \mathrm{~nm}$. The comparison of AR, hydrogen peroxide/peroxidase UV/Vis assays ruled out future use of ECL that was not sensitive to low concentrations of hydrogen peroxide. The yield, sensitivity, quantification and detection limit of the enzyme-linked $\mathrm{H}_{2} \mathrm{O}_{2}$ assay and LC-ESI-MS of were compared to AR and the hydrogen peroxide/peroxidase assay in vitro as well as in vivo. The UV/Vis versus LC-ESI-MS showed both qualitative and quantitative differences with respect to measured oxidation of AR in response to PMA.

\subsection{Characterization of Sensitivity for Detection of $\mathrm{H}_{2} \mathrm{O}_{2}$}

The enzyme-catalyzed oxidation of AR assay is a simple and sensitive method for measurement of the $\mathrm{H}_{2} \mathrm{O}_{2}$ production from RAW264.7 cells. This method allows detection of 5pmol $\mathrm{H}_{2} \mathrm{O}_{2}$ per $100 \mu \mathrm{l}$ in a 96-well fluorescence microplate in vitro assay (Zhou et al., 1997). Although enzymecatalyzed oxidation of AR assay is a sensitive method for measurement of $\mathrm{H}_{2} \mathrm{O}_{2}$, the signals were 
not strong and were typically below the safe limit of detection and quantification (LOQ). The lowest concentration of $\mathrm{H}_{2} \mathrm{O}_{2}$ that can be detected may give a reading not clearly resolved from the baseline. Our experiment showed lower than $0.5 \mathrm{nmol}$ of $\mathrm{H}_{2} \mathrm{O}_{2}$ per $200 \mu \mathrm{l}$ was below the LOQ to safely quantify yield of $\mathrm{H}_{2} \mathrm{O}_{2}$ in live cells. In addition, the LOQ for $\mathrm{H}_{2} \mathrm{O}_{2}$ using ECL was 1 nmol of $\mathrm{H}_{2} \mathrm{O}_{2}$ per $200 \mu \mathrm{l}$. As it was expected, the limit of sensitivity for the detection of $\mathrm{H}_{2} \mathrm{O}_{2}$ can be achieved by as little as 0.2 pmol per $2 \mu \mathrm{L}$ using LC-ESI-MS.

\subsection{Measurement of $\mathrm{H}_{2} \mathrm{O}_{2}$ Production}

Macrophages are scavenger cells capable of phagocytosis. The measurement of the $\mathrm{H}_{2} \mathrm{O}_{2}$ production during phagocytosis in RAW 264.7 cells was measured with the Amplex Red Hydrogen Peroxide/peroxidase assay. The powerful carcinogenic substance PMA can directly activate protein kinase C (PKC) to activate NAPDPH oxidase (Swindle et al., 2002). When we RAW 264.7 cells were stimulated with $1 \mu \mathrm{M}$ of PMA for $5 \mathrm{~min}$, a high level of $\mathrm{H}_{2} \mathrm{O}_{2}(\mathrm{Mean} \pm \mathrm{SE}$ : $\left.819 \pm 5.26 \mathrm{E}^{-05} \mu \mathrm{mol}\right)$ was produced. Swindle, Hunt, \& Coleman (2002) identified superoxide as the major source of ROS after 3 to 7 minutes incubation with PMA using pholasin-dependent chemiluminescence. The inflammatory ligand oxLDL may activate macrophages and increase $\mathrm{H}_{2} \mathrm{O}_{2}$ by macrophage-derived foam cells (Karunakaran et al., 2016 and Rajagopalan et al., 1996). The treatment of macrophages with oxLDL induced the production of $\mathrm{H}_{2} \mathrm{O}_{2} 350 \mu \mathrm{mol} / \mathrm{L}$ to 450 $\mu \mathrm{mol} / \mathrm{L}$ (Sukhanov et al., 2006). Similarly, our result showed that when macrophages were incubated with oxLDL, they produced up to $170 \mu \mathrm{mol}\left(\mathrm{Mean} \pm \mathrm{SE}: 170 \pm 2.09 \mathrm{E}^{-05} \mu \mathrm{mol}\right)$ of $_{2} \mathrm{O}_{2}$ per $200 \mu \mathrm{L}$. Solid aggregates of oxLDL can activate macrophages and trigger inflammatory phagocytic activation leading to the release of free radicals and create more oxLDL. Microbeads were coated with oxLDL to and used in a phagocytosis assay (Vance et al., 2016). Solid aggregates 
of oxLDL can activate macrophage engulfment and produce $\mathrm{H}_{2} \mathrm{O}_{2}$ (Mean \pm SE: $250 \pm 2.15 \mathrm{E}^{-05}$ $\mu \mathrm{mol})$ as measured by the production and accumulation of resorufin. The signal was specific as demonstrated by the addition of catalase and SOD. The SOD and catalase enzymes lowers superoxide concentration by catalyzing the superoxide into hydrogen peroxide and oxygen while catalase promotes the degradation of $\mathrm{H}_{2} \mathrm{O}_{2}$ to $\mathrm{O}_{2}$ and $\mathrm{H}_{2} \mathrm{O}$. Addition of SOD and Catalase prior to addition of oxLDL coated beads, macrophages decreased production of $\mathrm{H}_{2} \mathrm{O}_{2}$ (Mean $\pm \mathrm{SE}$ : 0.185 $\left.\mu \mathrm{mol} \pm 8.33 \mathrm{E}^{-06}\right)$. When macrophages were incubated with oxLDL for 2 hours, intracellular catalase activity increased while activity of SOD remain consistent (Sukhanov et al., 2006 and Hultén et al., 2007). Macrophages upregulate catalase activity to restore ROS balance in response to oxidative stress (Hultén et al., 2007).

\subsection{Luminol Dependent Chemiluminescent}

ECL is sensitive and quantitatively detects $\mathrm{H}_{2} \mathrm{O}_{2}$ since luminol oxidized by $\mathrm{HRP}$ using $\mathrm{H}_{2} \mathrm{O}_{2}$ in $1: 1$ stoichiometric to produce aminophthalate with light emission detectable to the $0.2 \mathrm{nmol}$ level. The ECL assay allowed detection of HRP up to $0.01 \mathrm{ng}$ and the LOQ for $\mathrm{H}_{2} \mathrm{O}_{2}$ was 10 nmol of $\mathrm{H}_{2} \mathrm{O}_{2}$ per $200 \mu 1$. It is clear from our data that ECL is not as sensitive as by mass spectrometry combined enzyme-catalyzed oxidation of AR assay. Although some studies suggested another enhancer such as Diogenes to increase sensitivity, it did not mention the LOQ to be comparable to our method (Yamazaki et al., 2011).

\subsection{Mass spectrometry}

Fluorescent resourfin can be detected by applying liquid chromatography with electrospray ionization and tandem mass spectrometry (LC-ESI-MS) at $214 \mathrm{~m} / \mathrm{z}[\mathrm{M}+\mathrm{H}]$ to an in vitro reaction (Florentinus-mefailoski et al., 2013). Resorufin from the cellular media in $0.1 \%$ formic acid 
produced an intense peak at $214 \mathrm{~m} / \mathrm{z}$ by LC-ESI-MS using isocratic HPLC and SIM. The collection of resorufin from $20 \mu \mathrm{L}$ of cellular media analyzed by LC-ESI-MS at $214 \mathrm{~m} / \mathrm{z}$ [M+H] was not above LOQ. The resorufin from a larger volume of cellular media may have to be concentrated to provide a signal that is well resolved from baseline.

Tyrosine phosphorylation was involved in the activation of the macrophage respiratory burst (Bassal et al., 1997). Sodium orthovanadate is a phosphor-tyrosine phosphatase (PTP) inhibitor that enhance the respiratory burst in neutrophils or macrophages (Green, Hamilton, \& Phillips, 1992). Studies showed that tyrosine kinase activity increased by PMA which is associated with the respiratory burst (Bassal et al., 1997). Previously, the addition of vanadate prior to triggering the respiratory burst, enhanced the effect of the tyrosine kinases activity resulting in an increase in respiratory burst but had no effect in our experiments. There was an apparent increase in absorbance at $570 \mathrm{~nm}$ in response to treatment with PMA even after centrifugation (Figure 3.10). but no effect of PMA was observed by LC-ESI-MS. Many studies have showed that PMA induced accumulation of RNA and enzymes that are related to oxygen-dependent metabolism and apoptotic cells (Dolgushin et al., 2013). Thus, it was proposed that PMA induced cell secretion that cannot be removed by centrifugation at $14800 \mathrm{rpm}$ and may interfere the absorbance of the resorufin while measuring intensity at $214 \mathrm{~m} / \mathrm{z}$ using LC-ESI-MS was not effected by PMA induced cell secretion. Thus, further experiments are required to determine the source of the discrepancy between UV/Vis versus LC-ESI-MS. 


\section{CHAPTER 5:CONCLUSION}

If the ROS generated in cells can be measured and analyzed precisely, it can be employed to evaluate immune function in response to ligands and drugs. In this study, a novel enzyme linked cellular assay to detect $\mathrm{H}_{2} \mathrm{O}_{2}$ produced by cultured macrophages during the phagocytosis of oxLDL coated beads by the exogenous provision of Amplex Red and HRP monitored by LC-ESI-MS. In the presence of $\mathrm{HRP}$ and Amplex red, the $\mathrm{H}_{2} \mathrm{O}_{2}$ produced by the cells reacted in a 1:1 stoichiometric ratio to produce the red fluorescent oxidation product, resorufin that may be quantified by LC-ESI-MS. Resorufin can be detected by fluorescence using excitation of $570 \mathrm{~nm}$ and emission of $585 \mathrm{~nm}$ at $0.5 \mathrm{nmol}$ to $1 \mathrm{nmol}$ level that showed a safe detection limit similar to ECL. The small amount of $\mathrm{H}_{2} \mathrm{O}_{2}$ produced by cultured macrophages, while biologically significant, was below the limit of safe detection and quantification by UV/Vis methods. The quantification of resorufin by LC-ESI-MS at $214 \mathrm{~m} / \mathrm{z}[\mathrm{M}+\mathrm{H}]$ allowed for detection as low as $0.2 \mathrm{pmol}$ level. Although, quantified $\mathrm{H}_{2} \mathrm{O}_{2}$ production level by macrophages in response to the inflammatory ligands from $20 \mu \mathrm{L}$ were not above the $\mathrm{LOQ}$, there was a trend to greater $\mathrm{H}_{2} \mathrm{O}_{2}$ production with inflammatory stimulation. The mass spectral detection method to an enzyme couples cellular assay is a useful tool for sensitive detection of $\mathrm{H}_{2} \mathrm{O}_{2}$ in cells. Thus, it can be widely applied in biochemical research and in clinical trials for $\mathrm{H}_{2} \mathrm{O}_{2}$ detection techniques.

\section{Future Work}

LC-ESI-MS is a very sensitive method to detect as low as 0.2 pmol of $\mathrm{H}_{2} \mathrm{O}_{2}$. However, zip-tipping $20 \mu \mathrm{L}$ of resorufin from cellular media with $20 \mu \mathrm{L}$ injection into LC-ESI-MS is not sufficient. It is believed that increasing the volume to $1 \mathrm{ml}$ of cellular media collected over $\mathrm{C} 18$ with $20 \mu \mathrm{L}$ injection loop will allow for the quantification or $\mathrm{H}_{2} \mathrm{O}_{2}$ above the LOQ. 


\section{APPENDIX}

95\% famby-wise confidence leved

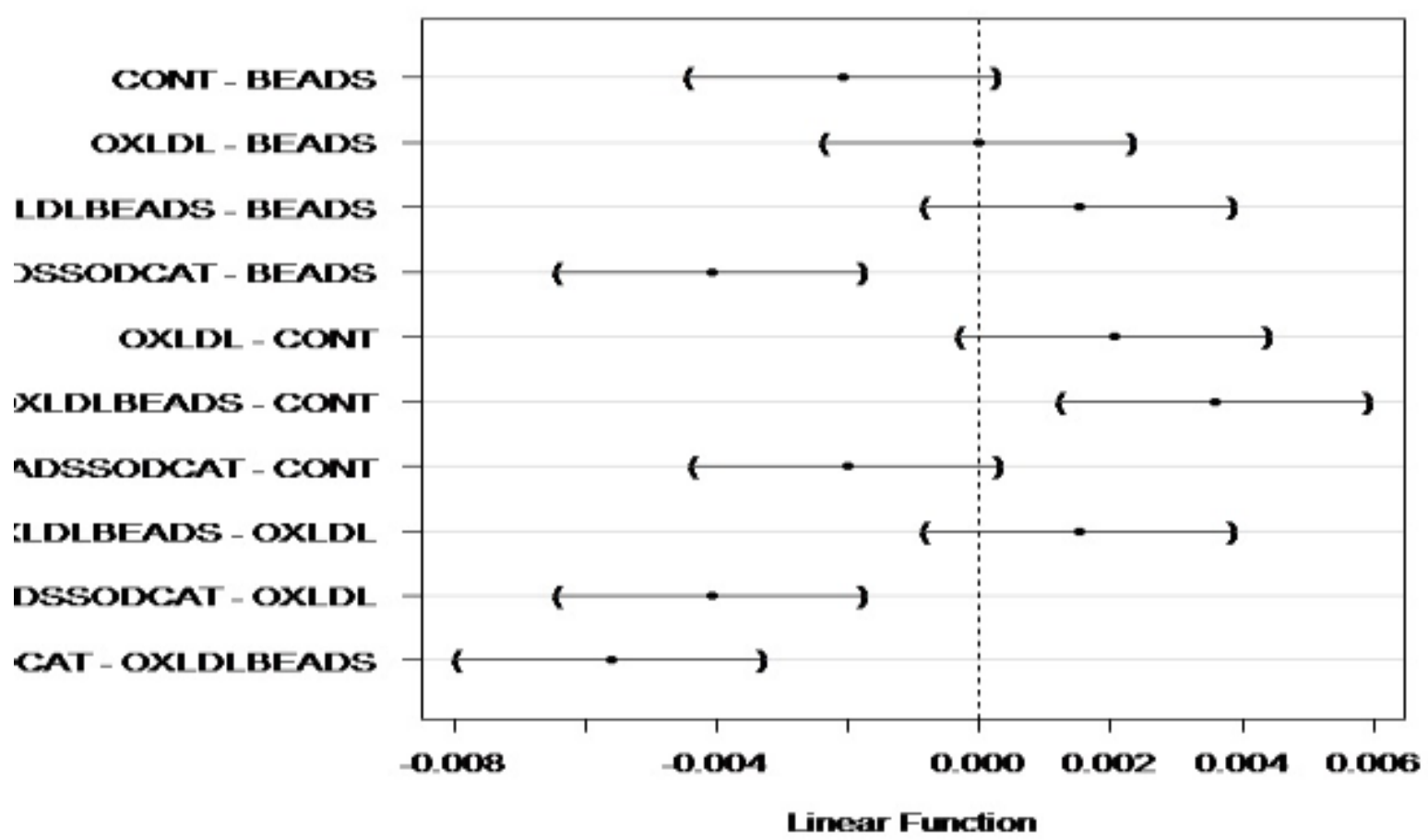

Figure A. $195 \%$ family-wise confidence level for simultaneous measurement of $\mathrm{H}_{2} \mathrm{O}_{2}$ production using the combination of enzyme-linked $\mathrm{H}_{2} \mathrm{O}_{2}$ radical assay. The confidence intervals using the Tukey method for each of the ten comparisons yields are shown. The pairwise comparisons indicated that OxLDL-beads are significantly different from the control. In addition, SOD and Catalase quench the signal from OxLDL-beads are also significantly different. 


\section{$95 \%$ family-wise confidence level}

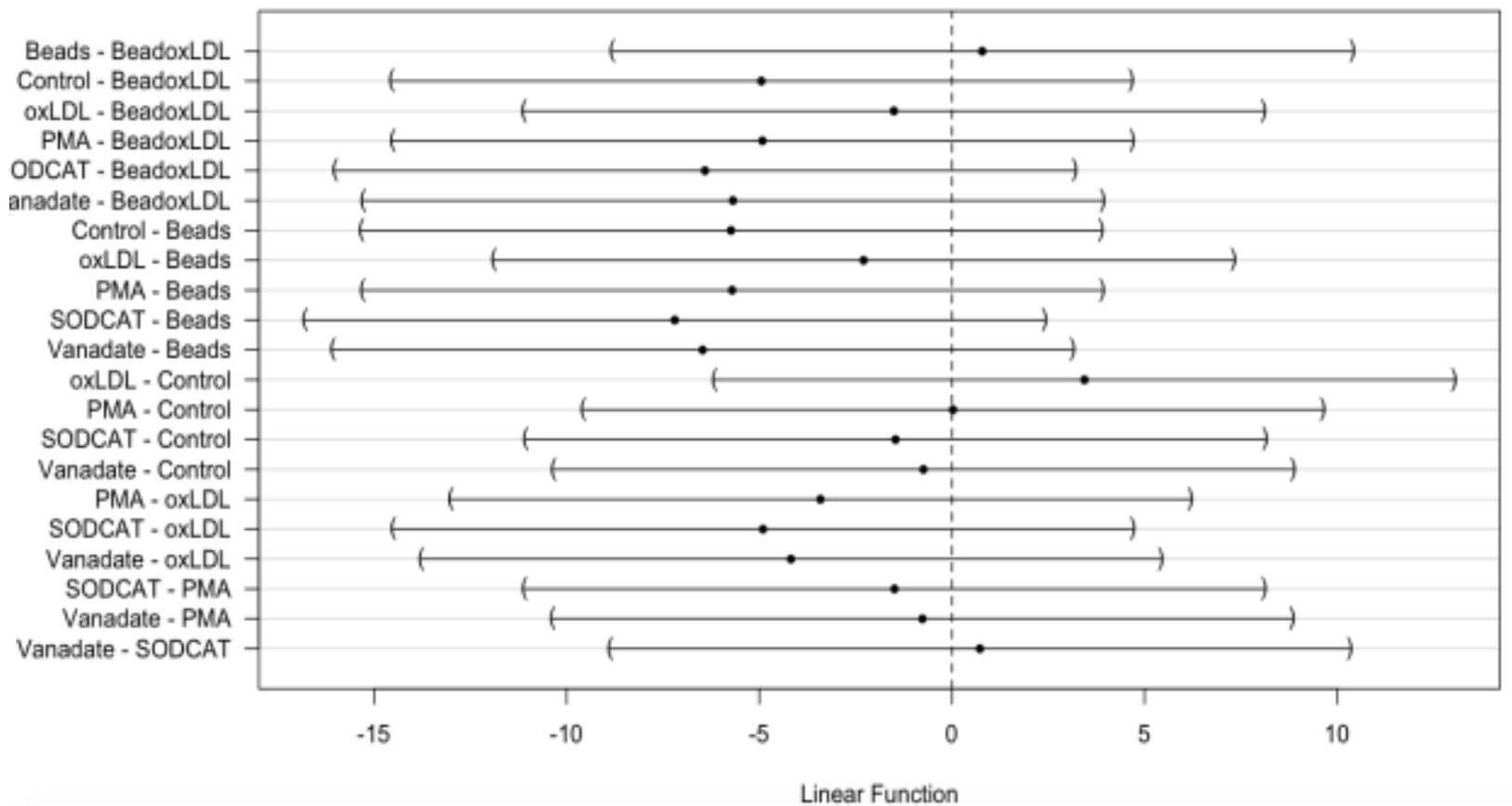

Figure A. $295 \%$ family-wise confidence level for simultaneous measurement of $\mathrm{H}_{2} \mathrm{O}_{2}$ production analyzed by LC-ESI-MS. The confidence intervals using the Tukey method for each of the ten comparisons yields are shown. The pairwise comparisons indicated that there no significantly different from the control. 


\section{REFERENCES}

Aderem, A., \& Underhill, D. M. (1999). Mechanisms of phagocytosis in macrophages dol:10.1146/annurev.immunol.17.1.593

Balasaheb, S., \& Pal, D. (2015). RSC Advances. RSC Advances, 5, 27986-28006. https://doi.org/10.1039/C4RA13315C

Bassal, S., Liu, Y. S., Thomas, R. J. S., \& Phillips, W. A. (1997). Phosphotyrosine phosphatase activity in the macrophage is enhanced by lipopolysaccharide, tumor necrosis factor a , and granulocyte $r$ macrophage-colony stimulating factor : correlation with priming of the respiratory burst, 343-352.

Bedard, K., \& Krause, K. (2007). The NOX Family of ROS-Generating NADPH Oxidases : Physiology and Pathophysiology, 245-313. https://doi.org/10.1152/physrev.00044.2005.

Birben, E., Sahiner, U. M., Sackesen, C., Erzurum, S., \& Kalayci, O. (2012). Oxidative Stress and Antioxidant Defense, (January), 9-19.

Babior, B.M., Kipnes, R.S., Curnutte, J.T. (1973). Biological defense mechanisms. The production by leukocytes of superoxide, a potential bactericidal agent Journal of Clinical Investigation, 52 (3), 741-744.

Baehner, R. L., Murrmann, S. K., Davis, J., \& Johnston, R. B. (1975). The role of superoxide anion and hydrogen peroxide in phagocytosis-associated oxidative metabolic reactions. Journal of Clinical Investigation, 56(3), 571-576.

Bae, Y. S., Lee, J. H., Choi, S. H., Kim, S., Almazan, F., Witztum, J. L., \& Miller, Y. I. (2009). Macrophages generate reactive oxygen species in response to minimally oxidized low-density lipoprotein: Toll-like receptor 4- and spleen tyrosine kinase-dependent activation of NADPH oxidase 2. Circulation Research, 104(2), 210-218.

Bassal, S., Liu, Y. S., Thomas, R. J. S., \& Phillips, W. A. (1997). Phosphotyrosine phosphatase activity in the macrophage is enhanced by lipopolysaccharide, tumor necrosis factor $\alpha$, and granulocyte/macrophage-colony stimulating factor: Correlation with priming of the respiratory burst. Biochimica Et Biophysica Acta - Molecular Cell Research, 1355(3), 343-352.

Bayne, A.-C. V., Mockett, R. J., Orr, W. C., \& Sohal, R. S. (2005). Enhanced catabolism of mitochondrial superoxide/hydrogen peroxide and aging in transgenic Drosophila. Biochemical Journal, 391(Pt 2), 277-284.

Bedard, K., \& Krause, K. -. (2007). The NOX family of ROS-generating NADPH oxidases: Physiology and pathophysiology. Physiological Reviews, 87(1), 245-313 
Bhandari, A., Kim, W., \& Hohn, K. (2010). Luminol-based enhanced chemiluminescence assay for quantification of peroxidase and hydrogen peroxide in aqueous solutions: Effect of reagent $\mathrm{pH}$ and ionic strength. Journal of Environmental Engineering, 136(10), 1147-1152.

Birben, E., Sahiner, U.M., Sackesen, C., Erzurum, S., Kalayci, O. (2012). Oxidative stress and antioxidant defense. World Allergy Organization Journal, 5 (1), 9-19

Boveris, A., Cadenas, E., \& Stoppani, A. O. (1976). Role of ubiquinone in the mitochondrial generation of hydrogen peroxide. Biochemical Journal, 156(2), 435-444.

Boveris, A., Oshino, N., \& Chance, B. (1972). The cellular production of hydrogen peroxide. Biochemical Journal, 128(3), 617-630

Chance, B., Sies, H., \& Boveris, A. (1979). Hydroperoxide metabolism in mammalian organs. Physiological Reviews, 59(3), 527-605

Davies, P., Drath, D.B., Engel, E.E., Huber, G.L. (1979). The localization of catalase in the pulmonary alveolar macrophage Laboratory Investigation, 40 (2), pp. 221-226.

Dikalov, S., Griendling, K. K., \& Harrison, D. G. (2007). Measurement of Reactive Oxygen Species in Cardiovascular Studies. Hypertension, 49(4), 717-727.

Dolgushin, I. I., Markova, V. A., Savochkina, A. Y., \& Pegushina, I. V. (2013). Oxygen-dependent metabolism of intact and activated neutrophil granulocytes of the saliva. Bulletin of Experimental Biology and Medicine, 156(2), 239-241

Epelman, S., Lavine, K. J., \& Randolph, G. J. (2014). Origin and Functions of Tissue Macrophages. Immunity, 41(1), 21-35.

Finkel, T. H., Pabst, M. J., Suzuki, H., Guthrie, L. A., Forehand, J. R., Phillips, W. A., \& Johnston Jr., R. B. (1987). Priming of neutrophils and macrophages for enhanced release of superoxide anion by the calcium ionophore ionomycin. implications for regulation of the respiratory burst. Journal of Biological Chemistry, 262(26), 12589-12596.

Finkel, T., \& Holbrook, N. J. (2000). biology of ageing, 408(November), 239-247.

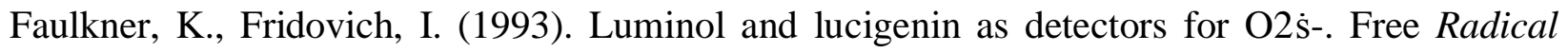
Biology and Medicine, 15 (4), 447-451.

Fleury, C., Mignotte, B., \& Vayssière, J. -. (2002). Mitochondrial reactive oxygen species in cell death signaling. Biochimie, 84(2-3), 131-141.

Florentinus-mefailoski, A., Safi, F., \& Marshall, J. G. (2013). ScienceDirect Enzyme Linked Immuno Mass Spectrometric Assay ( ELIMSA ). Journal of Proteomics, 96, 343-352. 
Giorgio, M., Trinei, M., Migliaccio, E., \& Pelicci, P. G. (2007). Hydrogen peroxide: A metabolic by-product or a common mediator of ageing signals? Nature Reviews Molecular Cell Biology, 8(9), 722-728.

Green, S. P., Hamilton, J. A., \& Phillips, W. A. (1992). Zymosan-triggered tyrosine phosphorylation in mouse bone-marrow-derived macrophages is enhanced by respiratory-burst priming agents, 288, 427-432.

Halliwell, B., \& Gutteridge, J. M. (1984). Oxygen toxicity, oxygen radicals, transition metals and disease. Biochemical Journal, 219(1), 1-14.

Han, J., \& Nicholson, A. C. (1998). Lipoproteins modulate expression of the macrophage scavenger receptor. American Journal of Pathology, 152(6), 1647-1654.

Holmström, K. M., \& Finkel, T. (2014). Cellular mechanisms and physiological consequences of redox-dependent signalling. Nature Publishing Group, 15(6), 411-421.

Hultén, L. M., Ullström, C., Krettek, A., Reyk, D. Van, Marklund, S. L., Dahlgren, C., \& Wiklund, O. (2007). Human macrophages limit oxidation products in low density lipoprotein, 11, 1-11.

Imai, H., Nakagawa, Y. (2003). Biological significance of phospholipid hydroperoxide glutathione peroxidase (PHGPx, GPx4) in mammalian cells (2003) Free Radical Biology and Medicine, 34 (2), 145-169.

Itabe, H. (2009). Oxidative modification of LDL: Its pathological role in atherosclerosis. Clinical Reviews in Allergy and Immunology, 37(1), 4-11.

Kohno, M. (2010). Applications of Electron Spin Resonance Spectrometry for Reactive Oxygen Species and Reactive Nitrogen Species Research. Journal of Clinical Biochemistry and Nutrition, 47(1), 1-11.

Karlsson, M., Kurz, T., Brunk, U. T., Nilsson, S. E., Frennesson, C. I. (2010). What does the commonly used DCF test for oxidative stress really show? Biochem J. (428), 183-190

Kalyanaraman, B., Darley-Usmar, V., Davies, K.J.A., Dennery, P.A., Forman, H.J., Grisham, M.B., Mann, G.E., Moore, K., Roberts II, L.J., Ischiropoulos, H. (2012). Measuring reactive oxygen and nitrogen species with fluorescent probes: Challenges and limitations. Free Radical Biology and Medicine, 52 (1), 1-6

Karunakaran, D., Geoffrion, M., Wei, L., Gan, W., Richards, L., Shangari, P., . . Rayner, K. J. (2016). Targeting macrophage necroptosis for therapeutic and diagnostic interventions in atherosclerosis. Science Advances, 2(7), e1600224. 
Lee, R., Margaritis, M., Channon, K. M., \& Antoniades, C. (2012). Evaluating Oxidative Stress in Human Cardiovascular Disease : Methodological Aspects and Considerations, 2504-2520.

Lee, S. J., Hoa, C., Quach, T., Jung, K., Paik, J., Lee, J. H., ... Lee, K. (n.d.). Oxidized LowDensity Lipoprotein Stimulates Macrophage 18 F-FDG Uptake via Hypoxia-Inducible Factor-1 a Activation Through Nox2-Dependent Reactive Oxygen Species Generation, 1699-1706.

Lee, S. J., Quach, C. H. T., Jung, K. -., Paik, J. -., Lee, J. H., Park, J. W., \& Lee, K. -. (2014). Oxidized low-density lipoprotein stimulates macrophage $18 \mathrm{~F}-\mathrm{FDG}$ uptake via hypoxia-inducible factor-1 $\alpha$ activation through Nox2-dependent reactive oxygen species generation. Journal of Nuclear Medicine, 55(10), 1699-1705.

Liu, S. X., Hou, F. F., \& Guo, Z. J. (2006). Advanced oxidation protein products accelerate atherosclerosis through promoting oxidative stress and inflammation [J]. Arterioscler Thromb Vasc Biol, 26(1).

McCord, J. M., \& Fridovich, I. (1969). Superoxide dismutase. an enzymic function for erythrocuprein (hemocuprein). Journal of Biological Chemistry, 244(22), 6049-6055.

McFarlane, C., Young, I. S., Hare, L., Mahon, G., \& McEneny, J. (2005). A rapid methodology for the isolation of intermediate-density lipoprotein: Characterization of lipid composition and apoprotein content. Clinica Chimica Acta, 353(1-2), 117-125.

Mohanty, J. G., Jaffe, J. S., Schulman, E. S., \& Raible, D. G. (1997). A highly sensitive fluorescent micro-assay of $\mathrm{H} 2 \mathrm{O} 2$ release from activated human leukocytes using a dihydroxyphenoxazine derivative. Journal of Immunological Methods, 202(2), 133-141.

Navas Díaz, A., García Sanchez, F., \& González García, J. A. (1996). Hydrogen peroxide assay by using enhanced chemiluminescence of the luminol-H2O2-horseradish peroxidase system: Comparative studies. Analytica Chimica Acta, 327(2), 161-165.

Nimse, S.B., Pal, D. (2015). Free radicals, natural antioxidants, and their reaction mechanisms. RSC Advances, 5 (35), 27986-28006.

Ramos, M. C., Torijas, M. C., \& Navas Díaz, A. (2001). Enhanced chemiluminescence biosensor for the determination of phenolic compounds and hydrogen peroxide. Sensors and Actuators, B: Chemical, 73(1), 71-75.

Ray, P. D., Huang, B.-W., \& Tsuji, Y. (2012). Reactive oxygen species (ROS) homeostasis and redox regulation in cellular signaling. Cellular Signalling, 24(5), 981-990.

Rossi, F., Zatti, M. (1964). Biochemical aspects of phagocytosis in poly-morphonuclear leucocytes. NADH and NADPH oxidation by the granules of resting and phagocytizing cells. Experientia, 20 (1), 21-23. 
Rost, M., Karge, E., Klinger, W. (1998). What Do We Measure with Luminol-, Lucigenin- and Penicillin-amplified Chemiluminescence? 1. Investigations with Hydrogen Peroxide and Sodium Hypochlorite . Luminescence, 13 (6), 355-363

Rajagopalan, S., Meng, X. P., Ramasamy, S., Harrison, D. G., \& Galis, Z. S. (1996). Reactive oxygen species produced by macrophage-derived foam cells regulate the activity of vascular matrix metalloproteinases in vitro. Implications for atherosclerotic plaque stability. Journal of Clinical Investigation, 98(11), 2572-2579

Shen, L. -., Zhou, L., Wang, B. -., Pu, J., Hu, L. -., Chai, D. -., . . . He, B. (2008). Oxidized lowdensity lipoprotein induces differentiation of RAW264.7 murine macrophage cell line into dendritic-like cells. Atherosclerosis, 199(2), 257-264.

Steijger, O. M., Den Nieuwenboer, H. C. M., Lingeman, H., Brinkman, U. A. T., Holthuis, J. J. M., \& Smilde, A. K. (1996). Enhancement of peroxyoxalate chemiluminescence by copper(II) in flow injection analysis; optimization by factorial design analysis. Analytica Chimica Acta, 320(1), 99-105.

Stone, J. R. \& Yang, S. (2006). Hydrogen peroxide: a signaling messenger. Antioxid. Redox Signal. 8, 243-270.

Sukhanov, S., Higashi, Y., Shai, S. -., Itabe, H., Ono, K., Parthasarathy, S., \& Delafontaine, P. (2006). Novel effect of oxidized low-density lipoprotein: Cellular ATP depletion via downregulation of glyceraldehyde-3-phosphate dehydrogenase. Circulation Research, 99(2), 191200.

Swindle, E. J., Hunt, J. A., \& Coleman, J. W. (2002). A comparison of reactive oxygen species generation by rat peritoneal macrophages and mast cells using the highly sensitive real-time chemiluminescent probe pholasin: Inhibition of antigen-induced mast cell degranulation by macrophage-derived hydrogen peroxide. Journal of Immunology, 169(10), 5866-5873.

Thannickal, V. J., \& Fanburg, B. L. (2000). Reactive oxygen species in cell signaling. American Journal of Physiology - Lung Cellular and Molecular Physiology, 279(6 23-6), L1005-L1028.

Teahan, C., Rowe, P., Parker, P., Totty, N., Segal, A.W. (1987). The X-linked chronic granulomatous disease gene codes for the beta-chain of cytochrome b-245. Nature 327, 720-721.

Turrens, J. F., Alexandre, A., \& Lehninger, A. L. (1985). Ubisemiquinone is the electron donor for superoxide formation by complex III of heart mitochondria. Archives of Biochemistry and Biophysics, 237(2), 408-414.

Vance, D. T., Dufresne, J., Florentinus-mefailoski, A., Tucholska, M., Trimble, W., Grinstein, S., \& Marshall, J. G. (2016). A phagocytosis assay for oxidized low-density lipoprotein versus immunoglobulin G-coated microbeads in human U937 macrophages. Analytical Biochemistry, 
500, 24-34. https://doi.org/10.1016/j.ab.2016.01.007

Vladimirov, Y. A., \& Proskurnina, E. V. (2009). Free Radicals and Cell Chemiluminescence, 74(13), 1545-1566.

Weisiger, R. A., \& Fridovich, I. (1973). Superoxide dismutase. organelle specificity. Journal of Biological Chemistry, 248(10), 3582-3592.

Yamazaki, T., Kawai, C., Yamauchi, A., \& Kuribayashi, F. (2011). TMH A highly sensitive chemiluminescence assay for superoxide detection and chronic granulomatous disease diagnosis, 39(2), 41-45. https://doi.org/10.2149/tmh.2011-08

Yia-Herttuala, S., Palinski, W., Rosenfeld, M. E., Parthasarathy, S., Carew, T. E., Butler, S., . . Steinberg, D. (1989). Evidence for the presence of oxidatively modified low density lipoprotein in atherosclerotic lesions of rabbit and man. Journal of Clinical Investigation, 84(4), 1086-1095.

Yoshida, H., Ureshino, K., Ishida, J., Nohta, H., \& Yamaguchi, M. (1999). Chemiluminescent properties of some luminol related compounds (II). Dyes and Pigments, 41(3), 177-182.

Woo, H. A., Yim, S. H., Shin, D. H., Kang, D., Yu, D. -., \& Rhee, S. G. (2010). Inactivation of peroxiredoxin I by phosphorylation allows localized $\mathrm{H} 2 \mathrm{O} 2$ accumulation for cell signaling. Cell, 140(4), 517-528.

Zelko, I.N., Mariani, T.J., Folz, R.J. (2002). Superoxide dismutase multigene family: A comparison of the CuZn-SOD (SOD1), Mn-SOD (SOD2), and EC-SOD (SOD3) gene structures, evolution, and expression. Free Radical Biology and Medicine, 33 (3), 337-349.

Zhou, M., Diwu, Z., Panchuk-voloshina, N., \& Haugland, R. P. (1997). A Stable Nonfluorescent Derivative of Resorufin for the Fluorometric Determination of Trace Hydrogen Peroxide: Applications in Detecting the Activity of Phagocyte NADPH Oxidase and Other Oxidases, 168(253), 162-168. 
